\title{
Optimal labor and capital utilization by financial firms: evidence from the German property and casualty insurance industry
}

\section{Martin Eling $^{1}$ (D) Martin Lehmann ${ }^{1} \cdot$ Philipp Schaper $^{1}$}

Accepted: 26 October 2021 / Published online: 26 November 2021

(c) The Author(s) 2021

\begin{abstract}
Motivated by discussions whether financial firms use too much equity capital and labor, we analyze the input utilization in the German property and casualty (p/c) insurance industry in a newly constructed sample of firm-level data in the period 1956-2019. An earlier study for the U.S. (Cummins and Nini, J Financial Serv Res 21(1-2):15-53, 2002) finds that $\mathrm{p} / \mathrm{c}$ insurers over-utilize capital. Compared to this study, our large historical dataset exhibits less heterogeneity and thus allows a cleaner identification of the impact of firm characteristics on input factor utilization. We show that German p/c insurers have substantial cost savings potential and that labor input is the main driver of inefficiency. We also document severe differences in firm characteristics driving the utilization of labor. Our results contribute to both the academic discussion on productivity and efficiency in financial services as well as to the political discussion on the future of work and capital regulation in this sector.
\end{abstract}

Keywords Insurance $\cdot$ Multi-stage data envelopment analysis · Input utilization

JEL Classification $\mathrm{D} 23 \cdot \mathrm{G} 22 \cdot \mathrm{L} 11$

\section{Introduction}

A large stream of literature has investigated the productivity and efficiency of the insurance industry (e.g., Cummins and Nini 2002; Cummins and Xie 2008, for the U.S. and Hussels and Ward 2007; Luhnen 2009; Trigo-Gamarra and Growitsch

Martin Eling

martin.eling@unisg.ch

Martin Lehmann

martin.lehmann@unisg.ch

Philipp Schaper

philipp.schaper@unisg.ch

1 Institute of Insurance Economics, University of St. Gallen, Girtannerstrasse 6, 9010 St. Gallen, Switzerland 
2010, for Germany). In this context and in other parts of the academic literature (e.g., Eling et al. 2007) the optimal amount of equity capital has been critically discussed. Cummins and Nini (2002) investigate the large increase of equity capital in the U.S. property and casualty $(\mathrm{p} / \mathrm{c})$ insurance industry after the introduction of riskbased capital standards in the 1990s and find that insurers use too much equity capital compared to how much they should be using based on efficiency considerations. A side note that is also documented but not further studied is that insurers use too much labor and business services. One of their main results is that the use of equity capital is inefficient and not a rational response to market conditions.

Recently, the second input factor, i.e., the amount of labor, used in the insurance industry has been in focus of a lot of discussion (see e.g., Johansson and Vogelgesang 2015; Deloitte 2018), with some studies arguing that a significant different workforce is needed in the future (Malhotra 2015) or that existing workforce might be used for more productive, customer-focused activities (Sandner et al. 2020). However, this is not a new discussion. With the invention of semiconductors and personal computers, the third industrial revolution has already substantially changed the production process in most industries (Schwab 2016); the insurance industry has been one of the early-adopters of such technology with computer systems used e.g., for statistical analysis on risk classification and claims management (Harris and Katz 1991). Because of increasing computation capabilities and falling computer prices former manual routine tasks are now increasingly automated and workers with non-routine, more complex tasks are increasingly supported by computers (Goldin and Katz 1998; Autor et al. 2003).

This development had and still has a well-documented influence on the labor market (e.g., Katz and Murphy 1992; Autor et al. 2003; Goos and Manning 2007; Autor and Dorn 2013). For example, the demand for labor for routine tasks-especially in the manufacturing industry-has decreased over the past decades, with the existing labor supply being reallocated in lower paid non-routine service jobs (Autor and Dorn 2013). Furthermore, workers with problem solving skills have become more productive and efficient because of the decreasing computation costs (Autor and Dorn 2013). With the reallocation of jobs from routine to nonroutine tasks, we have not observed a decline in overall employment, but rather a job polarization (Spitz-Oener 2006; Goos and Manning 2007; Goos et al. 2014).

According to Schwab (2016), we are now facing the fourth industrial revolution, where the physical and digital worlds are merging, which may further change the structure of the labor market. Frey and Osborne (2017) show that new technology advances will put $47 \%$ of jobs in the U.S. at a high risk of automatization within the next two decades. ${ }^{1}$ Due to the high degree of automatization, the labor input might be substituted with technology and thus capital investments. The reduced labor volume may be counteracted by the increasing capital volume (Autor et al. 2003; Frey and Osborne 2017). Furthermore, technological advances such as artificial intelligence and machine learning might have the potential to even make many non-routine service jobs redundant (Brynjolfsson and McAfee 2011).

\footnotetext{
1 Bonin et al. (2015) argue that the results rather show single tasks than complete job profiles. For Germany, they find that $42 \%$ of tasks can be automatized, which would affect $12 \%$ of the German work force.
} 
Fig. 1 Capital and labor usage in German $\mathrm{p} / \mathrm{c}$ insurance industry (standardized to 1 in 1956 , 2019 real values)

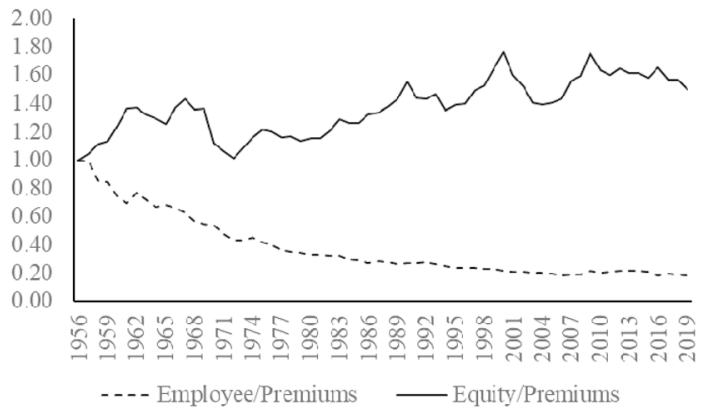

In this paper, we analyze this fundamental transition process using an important subsector of the economy with panel data that covers both the third and the beginning of the fourth industrial revolution. We study the usage of labor and capital and their impact on productivity and efficiency in the German p/c insurance industry from 1956 to 2019. The consideration of the insurance industry is advantageous not only because of its economic importance, ${ }^{2}$ but also because it was among the early adaptors of IT with many routine tasks being automatized early on (Harris and Katz 1991). Another advantage is that-as a service industry-labor and capital constitute the two central inputs in this industry, while other input factors such as materials are negligible. We also note that (as documented by Gomber et al. 2017) the insurance industry is heavily underexplored in terms of research on the impact of digitalization and the role of new technologies.

To emphasize the economic magnitude and importance of our analysis, Fig. 1 shows the capital and labor usage in the German p/c insurance industry using two simple measures (i.e., the number of employees and equity, each divided by insurance premium as a central revenue measure in insurance). The results show that the usage of labor has steadily decreased by $82 \%$ over the last 63 years, while the usage of capital was more volatile and increased by $50 \%$.

We analyze the input utilization of insurance companies in a large historical dataset which exhibits less heterogeneity than the U.S. data considered so far, i.e., we consider the German p/c insurance industry with firm-level data from 1956 to 2019. The extremely long sample period allows us to analyze unrevealed questions regarding input utilization in the insurance industry. Especially, it allows analyzing the impact of the business environment on the utilization of inputs. With the computerization and digitalization of the insurance industry, one may expect that capital becomes more and labor less important. Furthermore, given the recent trends towards market consolidation, one might also expect a reduction in the over-utilization of input factors over time, which needs to be revealed empirically.

\footnotetext{
${ }^{2}$ According to Swiss Re Institute (2019), the global insurance premiums are USD 5.2 trillion in 2018 (6.1\% of the global GDP). The German insurance market has premiums of USD 241 billion (145 billion non-life, 96 billion life), which is $6.0 \%$ of the German GDP. In terms of premium volume, the German non-life insurance sector has been the third largest insurance market worldwide and the largest in Europe in 2018 .
} 
Our paper contributes to the ongoing debate of utilization of equity capital and labor in a competitive market environment (e.g., Cummins and Nini 2002). We apply the frontier efficiency methodology, a widespreach approach in performance research (Dyckhoff and Ahn 2010; Ahn and Le 2015), which analyzes efficiency based on a benchmark mechanism that compares firms against best-in-class firms. These efficiency methodologies allow us to determine the optimal mix of business inputs to produce a given amount of outputs in comparison to best-in-class firms. The unusual long time period considered in our analysis allows us to assess the impact of the business. To our knowledge we are among the first to focus on the usage of input factors. Cummins and Nini (2002) investigate the usage of equity capital (but not labor) after the introduction of the U.S. risk-based capital standards.

Related papers are Cummins and Rubio-Misas (2006), which analyze the impact of the European wide deregulation on the Spanish insurance industry in the period 1989-1998. Their results show that many small, inefficient, financially underperforming insurance firms vanished, and the overall market has become more productive. Eling and Schaper (2017) find that adverse business conditions force managers to conduct more productivity-enhancing activities (e.g., cost-savings programs) and that some European life insurers over-utilize equity capital between 2002 and 2013. Various studies have analyzed efficiency determinants in the insurance industry (Biener et al. (2016); Cummins and Xie (2008, 2013); Eling and Luhnen (2010a) and, in particular, Luhnen (2009) and Mahlberg and Url (2010)). The two latter studies look at the determinants of efficiency in the German p/c market, but for a shorter time period. Besides expanding the observation period, our paper digs deeper than these previous papers by looking how specific inputs (i.e., capital and labor) are utilized and how they individually drive cost (in-)efficiency.

Our results show that German $\mathrm{p} / \mathrm{c}$ insurers have substantial cost savings potential and that labor input is the main driver of inefficiency. We also document severe differences in firm characteristics driving the utilization of labor. Our research sheds light on the development of labor and capital usage for an important subsector of the economy. Given the recent use of technology in the insurance industry (see e.g., Gomber et al. 2017; Eling and Lehmann 2018) and questions on future labor needs (see e.g., Malhotra 2015; Deloitte 2018), our analysis not only covers an important and widely unexplored field, but is also highly relevant for insurance managers and public policy. The results documented in our paper are of relevance not only for the German insurance industry, but also for other European insurance markets with comparable regulation and industry structure (e.g., France and Italy) as well as for other parts of the financial services sector (e.g., banking and pension funds).

The remainder of this paper is structured as follows. In Sect. 2, we review the literature on efficiency measurement and input utilization. Section 3 presents our hypotheses with respect to labor. Section 4 outlines the methodology and data. In Sect. 5, we discuss the empirical results and Sect. 6 concludes. 


\section{Literature review}

Scholars have often investigated the cost efficiency of insurance companies and documented substantial potential for cost saving considering aggregated efficiency numbers. For example, Luhnen (2009) finds that German p/c insurers could save on average 52\% in costs for 1995-2006. For the period 1991-2006, Mahlberg and Url (2010) report even higher results for German insurance groups: $60 \%$ on average. For the German life insurance industry, Hussels and Ward (2007) and TrigoGamarra and Growitsch (2010) find average potential cost savings of $44 \%$ and $52 \%$ for 1991-2002 and 1997-2005, respectively. In their cross-European sample of life insurers, Eling and Schaper (2017) report a 43\% cost saving potential. Similar levels of cost inefficiency have been reported for the U.S. insurance industry (e.g., Cummins and Nini 2002; Cummins and Xie 2008). Researchers have analyzed the impact of specific firm factors (e.g., size, distribution channel, ownership, premium growth, internationalization) and environmental changes on efficiency values (Cummins and Rubio-Misas 2006; Cummins and Xie 2008; Luhnen 2009; Eling and Luhnen 2010a; Mahlberg and Url 2010; Biener et al. 2016; Eling and Schaper 2017).

As mentioned above, so far studies have not analyzed how specific inputs (i.e., capital and labor) are utilized and how they individually drive cost (in-)efficiency. To the best of our knowledge, only Cummins and Nini (2002) have analyzed specific firm factors driving the utilization of input factors in the insurance industry, in their case for the use of equity for the U.S. p/c insurance industry. They motivate their study with the rise of capitalization in the U.S. p/c insurance market during the 1990s and investigate whether the increase was a valid response to structural changes (e.g., due to the introduction of risk-based capital standards, the increasing attention to financial ratings or the more volatile business structure ${ }^{3}$ ) or if the rising capital levels are a true inefficiency leading to decreased performance. As their analysis of the impact of specific firm factors on the use of equity capital is also the foundation for the development of our hypotheses on labor usage, we briefly present their hypotheses.

Financial distress - Insurers hold capital to ensure solvency. Cummins and Nini (2002) argue that the probability of insolvency is related to an insurer's ability to diversify risk. They consider four measures of diversification. Three of them (diversification by line of business, geographical diversification, use of reinsurance) measure liability risk and one (percentage of risky assets) measures asset risk. Additionally, the volatility of the return on equity (ROE) is considered as a comprehensive measure taking underwriting and investment risk into account. The authors argue that firms with lower risk use less capital. In the context of financial distress and in relation to diversification, Cummins and Nini (2002) argue that large insurers can predict the average loss in their insurance pool more precisely (law of large numbers), so that they should be less prone to insolvency and less sensitive to large

\footnotetext{
${ }^{3}$ Over the years and decades, the options for insurance customers to diversify their risk have increased. Thus, they may hedge the more predictable risks by themselves and only use insurance for the more volatile risks (Cummins and Nini 2002).
} 
losses. Consequently, firm size should be inversely related to the utilization of equity capital.

Conflicts of interest - In the insurance industry, there are two type of ownership forms-mutual and stock insurers-which make it possible to analyze conflicts between owners and managers, ${ }^{4}$ and owners and policyholders. ${ }^{5}$ In mutual insurers, the owner and the policyholder are the same. This suggests some potential for owner-manager conflict for mutual insurers to use less equity capital than stock insurers. Moreover, mutual insurers may need less capital as they invest in less complex projects. However, these effects could be offset by mutuals' less access to capital markets (Cummins and Nini 2002). Cummins and Nini (2002) are ambiguous about the differences in capital utilization between the two organizational forms. In addition, managers control the paid premium of the policyholder between the time of premium payment and claim settlement. Risks with long settlement horizons allow managers to invest in projects they are profiting from. Like an owner-manager conflict, this situation can be resolved by reducing the amount of equity in firms with longer tailed business. A third potential conflict of interest arises from the information asymmetry between investors and managers. As p/c insurers have actuarial and accounting flexibility in estimating the claim reserves, investors may never know the true value of loss reserves. So, firms with greater information asymmetries might accumulate equity during profitable periods. However, as Cummins and Nini (2002) argue, these firms might not have the same access to the capital market and as a result, they use less equity capital.

Growth opportunities and product market interactions-Cummins and Nini (2002) argue that insurers that want to grow are expected to hold more equity capital to avoid raising expensive capital in the future. Moreover, they argue that insurers, which operate mainly in the commercial lines hold more equity capital because commercial customers are seeking financial stability and have low costs of switching their insurer.

Table 1 summarizes the findings from Cummins and Nini (2002), focusing on firm factors and equity utilization. The role of technology is not considered as a driver for capital usage. We might expect that more technology-prone insurers, ceteris paribus, will use more capital and less labor.

\footnotetext{
4 The owner-manager conflict exists because managers may have an incentive to take on extra risk that would increase their salary, but not necessarily the value of equity. However, to take on risky projects, managers need cash and available equity capital. Limiting the amount of equity would align the interests of owners and managers (Cummins and Nini 2002).

5 If policyholders and owners were two separate groups, the owner-policyholder conflict exists, because policyholders are paid first, and owners share the profit, which goes beyond the policyholders' payments. In this situation, the liability of owners is limited, and they have an interest in risky projects (in line with managers incentives). However, this behavior is anticipated by policyholders and decreases their willingness to pay for insurance. Thus, the insurers use equity capital to insure solvency to policyholders.
} 
Table 1 Hypotheses and results from Cummins and Nini (2002)

\begin{tabular}{|c|c|}
\hline Hypothesis & Result \\
\hline \multicolumn{2}{|l|}{ Financial distress } \\
\hline $\begin{array}{l}\text { The Herfindahl indices of premiums written by state and by line of business } \\
\text { will be positively related to capital utilization }\end{array}$ & Not supported \\
\hline $\begin{array}{l}\text { Firms with higher ratios of ceded loss reserves to direct plus assumed loss } \\
\text { reserves will use less capital }\end{array}$ & Supported \\
\hline $\begin{array}{l}\text { Firms with higher percentages of assets invested in stocks and real estate will } \\
\text { use more capital }\end{array}$ & Supported \\
\hline $\begin{array}{l}\text { Higher risk, as measured by the standard deviation of ROE, will be associated } \\
\text { with higher capital utilization }\end{array}$ & Not supported \\
\hline Capitalization will be inversely related to firm size & Supported \\
\hline \multicolumn{2}{|l|}{ Conflicts of interest } \\
\hline Mutuals will not utilize capital more or less intensively than stocks & Mutuals use less equity \\
\hline $\begin{array}{l}\text { The ratio of reserves to losses incurred will be inversely related to capital } \\
\text { utilization }\end{array}$ & Supported \\
\hline $\begin{array}{l}\text { Firms with higher information asymmetries between managers and owners } \\
\text { will be more highly leveraged than firms with lower information asym- } \\
\text { metries }\end{array}$ & Supported \\
\hline \multicolumn{2}{|l|}{ Growth opportunities and product market interactions } \\
\hline Firms with more growth opportunities will hold relatively more equity capital & Not supported \\
\hline $\begin{array}{l}\text { Capitalization will be inversely related to the percentage of an insurer's rev- } \\
\text { enues coming from personal lines of insurance }\end{array}$ & Supported \\
\hline
\end{tabular}

\section{Hypotheses development}

As providing insurance is labor intensive, labor expenses are the main part of the operating costs in insurance firms and a potential source of cost inefficiency (next to capital inefficiency which was the focus of Cummins and Nini 2002). ${ }^{6}$ Moreover, as most technological advances have either replaced or are complementing their employees, labor expenses probably offer the most room for improvement. Indeed, Cummins and Nini (2002) find that U.S. p/c insurers significantly use too much equity capital (85.8\%), but also too much labor (159.7\%).

Efficiency values are the result of a benchmark comparison. Assuming an input orientation, the focus of firms is to minimize the inputs (costs) to produce a given amount of outputs. Given fixed input prices, cost inefficiencies arise because firms use a higher amount of input than the best-practice firm(s). We also derive the utilization values from a best-practice comparison. As mentioned above, insurers hold equity capital to ensure their solvency. Because of regulation the decision on the amount of equity capital is not a completely free parameter that offers room for

\footnotetext{
${ }^{6}$ According to Cummins and Weiss (2013), for U.S. non-life insurers, $76.6 \%$ of operating expenses are for human services (i.e., labor expenses). For the Spanish insurance industry, Cummins et al. (2004) report that labor accounts for $67 \%$ of non-loss expenses. Comparable numbers for Germany are not available, because the respective data is not collected.
} 
managerial discretion, at least when it comes to the lower level. We thus expect that the equity capital usage in the insurance sector is less heterogenous than the labor usage, which offers more room for managerial discretion. There are several plausible reasons for the over-use of labor in insurance firms. One reason is that insurers need many different job profiles with specific knowledge along their value chain. This means that insurers need to hire a variety of job profiles, which are different in their management, e.g., lawyers, actuaries, IT consultants, sales agents, customer service representatives, asset managers, among others, leading to complexity and potential over-use of labor in some cases.

Another reason is that the German p/c insurance industry was highly regulated until the mid-1990s. The national insurance markets had previously been closed to other European competitors, which restricted the competition in each country. With the third generation of insurance directives, established in 1994, insurers have been allowed to operate with one single license in the whole European Economic Area (Hussels and Ward 2007; Mahlberg and Url 2010). Before 1994, the German p/c insurance industry had felt less competitive pressure, also due to their stable premium income and investment return. Following the idea of X-efficiency (Leibenstein 1966), the absence of competitive pressure could result in less efficiency and less pressure for cost saving behavior. Moreover, as managers often have an incentive to expand the business, the limited competition may have induced the hiring of more employees than needed. After 1994, competition increased and insurers needed to become more efficient and productive. ${ }^{7}$

In addition, technological improvements over the last decades may also have consistently transformed the production process in the insurance industry. Through automatization and standardization of processes, the insurers may have more employees than needed. Under Germany's strong labor laws, unions, and work councils in larger firms, reducing the workforce is more complicated than in other countries. For example, $50 \%$ (33\%) of the supervisory board consist of employee representatives, if the firm has more (less) than 2000 employees. These laws may limit the flexibility to lay off many employees. ${ }^{8}$ Recent technological developments

\footnotetext{
7 However, the empirical results are mixed. The results from Luhnen (2009) support that deregulation lead to an efficiency increase. Mahlberg and Url (2010) do not find that inefficient insurers improved their position after the deregulation significantly, but they improved their allocative efficiency, i.e., they use the right input mix. It might thus well be that also after deregulation competitive pressure is not high enough to eliminate all potential inefficiencies, also because significant market distortions still exist (e.g., restrictions in market entry because of high licensing and capital requirements).

8 One referee correctly argues that labor cannot be reduced as other input factors and thus might be considered as non-discretionary input variable. Indeed, due to labor market frictions (and maybe also a lack of competition) the workforce is not reduced without significant effort. However, technically it is well possible that the workforce can be reduced, both in the short and long run and we have seen such events in the history of insurance. The reason why in reality the workforce is not decreased and increased as it would be possible is thus less a technical problem, but the fact that both financial and non-financial barriers exist. Unions in Germany are powerful institutions and managers might be reluctant to seek the confrontation, if not an absolute must. Furthermore, there are significant costs of hiring and training staff and offering good and sustainable jobs without a "hire and fire" mentality is an important factor in motivating people. So overall, modelling labor as a non-discretionary input variable (which would mean that it cannot be reduced or increased technically) would in our view be an assumption that is too extreme and does not well reflect reality.
} 
(e.g., big data, internet of things, artificial intelligence) may further increase the over-utilization of labor.

In conclusion, we expect the utilization of labor to be the main driver of insurers' cost inefficiency. Due to technological developments and Germany's strong labor protection mechanisms, the utilization may have increased over the years, given that the workforce cannot be reduced in the short and medium term. We state our first hypothesis as follows:

\section{Hypothesis 1: Labor utilization is the main driver of cost inefficiency}

Based on insurance efficiency studies and results from other industries, we derive our hypotheses regarding the influence of firm variables on labor utilization. With respect to labor utilization there is, to the best of our knowledge, no specific empirical evidence from insurance research.

We have argued that labor utilization may be one source of German p/c insurers' inefficiency. However, we expect differences in the utilization of labor among insurers. In our view, there could be many explanations for the heterogenous use of labor. For example, some insurers may see an advantage in optimizing the capacity of their workforce, they have better possibilities to train and educate their staff, or they have better access to more motivated and educated employees. Therefore, insurers which can create an optimal working environment for their employees, have a competitive advantage. In the remainder of this section, we discuss firm characteristics, which may influence the utilization of labor.

Size-From manufacturing industry studies, there is evidence of the relation between firm size and labor efficiency. For example, in a five-country OECD study, van Ark and Monnikhof (1996) find that in 1990, an employee in a German manufacturer with 500 or more employees produced $12.2 \%$ more output than an average employee in the whole sample. In contrast, an employee in a small firm (0-9 employees) produced $22.9 \%$ less output than an average employee. Van Ark and Monnikhof (1996) find similar results for the years 1967 and 1977 and for France, the U.K., the U.S. and Japan. Leung et al. (2008) confirm the results and find a positive link between firm size and labor productivity for Canadian and U.S. nonmanufacturing firms, but they excluded the financial service industry. To date, the efficient use of labor in the insurance industry has not been studied. However, from general efficiency studies (which do not differentiate between the inefficient use of inputs) we know that large insurers tend to be more efficient (Cummins and Zi 1998; Cummins and Rubio-Misas 2006; Eling and Luhnen 2010a).

Larger firms may profit from economies of scale. With respect to labor, every firm needs some overhead employees, which of course increase in number when the company is growing. However, if the overhead does not grow at the same scale as the output-generating employees (e.g., sales agents, asset managers), larger firms can more easily finance their overhead as their relative costs decrease. Moreover, large insurers may find it easier to centralize certain jobs (e.g., claims management and settlement) and to redistribute the work. Consequently, they would operate at full capacity without needing to hire new employees. Furthermore, larger companies have the resources and the opportunities to train their staff, whereas smaller companies might not. For example, Duetsch and Struck (2014) show that more possibilities for development are one reason for greater job stability at larger firms. 
In a study of the impact of a firm's reputation on labor productivity, Stuebs and Sun (2010) find that more reputable firms are associated with higher labor efficiency. They argue that firms with a better reputation have a larger labor supply. Therefore, these firms have their pick of the best employees. Additionally, employees are more motivated by their firm's reputation. We think that they are also more pressured due to the large supply of labor. Size and reputation are not necessarily the same, nevertheless, in the insurance industry size could be indicative of reputation and brand. This leads to our second hypothesis.

Hypothesis 2: Larger insurers use less labor

Diversification of business lines-In the insurance literature, there are two lines of thought on the impact of business diversification on efficiency. The strategic focus hypothesis claims that insurers who concentrate on their core business are more efficient. In terms of labor utilization, specialized insurers can train and educate their employees to perform specific tasks. They also may have fewer business processes and can optimize and standardize them more easily. Thus, specialized insurers and their employees become more efficient because they do similar tasks repetitively.

In contrast, the conglomeration hypothesis postulates that insurers operating in more business lines should profit from the effects of synergy and are therefore more efficient. For example, they may need only one team for risk management, actuarial service, and human resources. Therefore, because they can share many of their resources, they may more readily operate at full capacity and have a more diversified business. Additionally, diversified insurers may have better brand recognition and, like large insurers, have access to more motivated employees.

The empirical evidence in the efficiency literature is quite mixed. For example, Luhnen (2009) shows that specialization in the German p/c insurance market (i.e., the strategic focus hypothesis) creates higher efficiency values. In contrast, Biener et al. (2016) show that Swiss property and casualty insurance conglomerates are more efficient. Other studies analyze the efficiency between specialized insurance groups (only p/c or life insurance) and diversified insurance groups (offering $\mathrm{p} / \mathrm{c}$ and life insurance). Their results are not consistent. For example, according to Cummins et al. (2010) the strategic focus is superior. In contrast, Mahlberg and Url (2003) find a positive relation between diversified insurance groups and cost efficiency. However, as we use diversification in p/c business lines, their results cannot be directly applied to our setting. Given our focus on the German market, we follow Luhnen's (2009) results and formulate the following hypothesis:

\section{Hypothesis 3: Specialized insurers use labor more efficiently}

Premium growth-Insurers that want to strategically grow must invest heavily in, for instance, marketing campaigns and new office equipment. Cummins and Nini (2002) hypothesize that insurers that want to grow must save up capital so that they do not have to raise it later. This argument may not apply to labor (i.e., insurers are not hiring employees before they start growing). Insurers may not conserve their labor force for later purposes; labor is an expensive resource. Insurers would first use the staff that they have while operating at full capacity. Thus, it seems reasonable to assume that insurers start hiring when they have an open position. But when they are already operating at full capacity or if they want to grow more aggressively, they need to hire more employees. This could lead to an inefficient use of labor, as 
new employees must be oriented and trained. More experienced employees might have to assist the new hires. Luhnen (2009) shows that German p/c insurers with higher growth rates are less cost efficient, which would be in line with our second reason. Based on our thoughts, we are ambivalent about this relationship. However, following Luhnen's (2009) results, we investigate:

Hypothesis 4: Insurers with higher premium growth rates over-utilize labor more

Distribution-Another important aspect of labor utilization is the choice of distribution channel. We analyze the difference between insurers with agencies (independent or exclusive) and those without-direct insurers-which make their sales usually via phone, internet or mail. In terms of operating expenses, direct insurers have lower costs as they, for example, save money on local branches with sales staff. Moreover, they profit from centralization of jobs. Additionally, as not all products can be easily sold via a direct distribution channel, their product portfolio and service may be less complex. Many studies compare direct writers (direct and exclusive agent insurers) with independent agent insurers and almost all of them find cost advantages for direct writers (e.g., Berger et al. 1997; Luhnen 2009). However, our data set does not allow us to divide direct writers into direct insurers and exclusive agent insurers as we have an identifier only for direct insurers. Therefore, we only compare direct insurers with agent (exclusive and independent) insurers. Due to the less complex business, we think that direct insurers do not need a lot of labor and furthermore, they can centralize jobs more efficiently. Thus, we hypothesize:

Hypothesis 5: Agent insurers use more labor than direct insurers

Regional factor-In line with the reputation hypothesis, we argue that insurers in regions with better quality of life (i.e., higher life expectancy, better education and higher income) have more productive labor. One reason could be that employers should have a larger labor supply in regions with better life quality. Thus, they can choose among the most productive candidates. Moreover, employees may be more productive as they are pressured by the larger supply. Furthermore, investigating particular components of life quality, Craig et al. (1997) find in a cross-country study that labor productivity is higher in countries with higher life expectancy, and, for example, Choudhry (2009) reveals a positive relationship between education and labor productivity. The relationship may well be two-directional: on the one hand, regions with more labor demand attract more labor supply. On the other hand, firms may be attracted to regions with a better labor supply, which would foster the competition for workers and may increase wages. Thus, in summary, we hypothesize:

Hypothesis 6: Insurers in regions with higher life quality use less labor

\section{Sample data and methodology}

\subsection{Data sources}

We consider the German p/c insurance industry (excluding health insurers), for which we have firm-specific historical data from annual reports for 1956 through 2019. We obtain the annual firm-level data for 1956 through 2015 from publications of the Hoppenstedt Versicherungsjahrbuch (Luhnen 2009; Mahlberg and Url 2010; 
Braun et al. 2015; Eling et al. 2020), which include all relevant firm information (i.e., financial data, organizational and distribution form). We manually collected the data from 1956 to 2010 from the physical books and the data from 2011 to 2015 from digital copies. The data for 2015 through 2019 we obtained from AM Best.

For the data envelopment analysis (DEA), we only include insurers with positive total and invested assets, equity, technical reserves, employees, losses and premium income. We collect input prices from several sources. We obtain price indices information from Deutsche Bundesbank and the compensation data from the German national account published by the Federal Statistical Office (Destatis). ${ }^{9}$ All monetary values are deflated to 2019 values and the values before year 2000 are converted into EUR values.

The final (unbalanced) sample for the DEA analysis consists of $298 \mathrm{p} / \mathrm{c}$ insurers with data on 9899 firm years. Over the entire period, the sample is highly representative of the German p/c insurance market covering on average approximately $90 \%$ of total premiums written. Our data exhibits less heterogeneity than other datasets considered so far, e.g., because there is less regulatory heterogeneity in the German dataset compared to the 50 U.S. state regulators. As we use the standard deviation of the ROE over the past three years as one independent variable (to measure income risk) in our regression analysis, the sample size in our regression analysis reduces to $291 \mathrm{p} / \mathrm{c}$ insurers and 8757 firm years. We report the sample size separately in each table of results.

\subsection{DEA methodology}

In an ideal situation, we would know the production function of an insurance company (i.e., how much of inputs it should use to produce a given amount of output). But as the production functions are typically unknown in the financial services industry, we determine each year the efficiency frontier from $\mathrm{p} / \mathrm{c}$ insurers in our sample.

A fully efficient firm is defined as the best practice or benchmark firm (Farrell 1957). This means that no other firm uses less input to produce the same amount of output (input orientation) or produces more output with the same the input (output orientation). All best practice firms in the sample built the efficient frontier per year. Every firm on the efficiency (benchmark) frontier has an efficiency score of 1, meaning that they are $100 \%$ efficient. Every other firm in the sample (not operating on the efficient frontier) is compared to a linear combination of efficient firms. Depending on their use of inputs, they have an efficiency score between 0 and 1 .

We use cost efficiency to determine the optimal input mix for each insurer. Cost efficiency is the product of technical and allocative efficiency. A firm is said to be

\footnotetext{
${ }^{9}$ For the period 2000-2019 this data is directly available. For 1991-2000 we use the compensation growth rates from a different sector including the financial service industry per federal state and apply them to the given compensation values from the year 2000. Prior the year 1991, we do not have compensation data per federal state, thus we apply the German compensation growth rates of this sector until 1970 and the consumer price index until 1956.
} 
technically efficient if it minimizes the input conditional on the output (Cummins and Weiss 2013). Every firm on the efficient frontier fulfills this condition. However, if we limit ourselves to technical efficiency, there is, for most insurers, still room for improvement because the technical efficiency values do not consider the optimal allocation of inputs. Only cost-efficient firms are technically and allocatively efficient. Therefore, we determine for each insurer an optimal cost-efficient insurer (i.e., a linear combination of cost-efficient insurers) and compare the inputs of both insurers.

We use the non-parametric mathematical programming approach (i.e., DEA), suggested by Charnes et al. (1978) to determine the efficient frontier and the costefficient insurer (see Dellnitz et al. 2018, for a methodological discussion). ${ }^{10}$ The optimal input mix $I^{* *}$ for a cost inefficient insurer $s(s=1,2, \ldots, S)$, which uses M inputs to produce $N$ outputs, is given by the solution $x(M \times 1$ vector $)$ of the following linear problem (assuming variable return to scale):

$$
\min _{x, \lambda^{s}}\left(p^{s}\right)^{T} x, \text { subject to } O \lambda^{s} \geq O^{s}, x \geq I \lambda^{s}, \lambda^{s} \geq 0,1^{T} \lambda^{s}=1,
$$

where $p^{s}$ is an $M \times 1$ input price vector of insurer $s, I$ is an $M \times S$ input matrix used by all insurer in the sample, $O$ is an $N \times S$ matrix of all outputs produced by all insurer and $O^{s}$ is the $N \times 1$ output vector for insurer $s$. The vector $\lambda^{s}$ is an $S \times 1$ intensity vector for insurer $s$ used to construct the optimal insurer $s^{*}$ as a convex combination of cost-efficient insurers. Let $p c^{s}=\sum_{i=1}^{M} p_{i}^{s} I_{i}^{s}$ be the total costs for producing the output $O^{s}$ for insurer $s$, where $p_{i}^{s}>0$ is the price and $I_{i}^{s}>0$ is the amount of input $i$. The cost efficiency $(C E)$ for insurer $s$ is defined as:

$$
C E^{s}=\frac{p c^{s *}}{p c^{s}}, \text { with } p_{i}^{s}=p_{i}^{s *} .
$$

\subsubsection{Output}

We apply the value-added approach, which is by far the most widespread method for measuring intangible insurance outputs (see e.g., Luhnen 2009; Eling and Luhnen 2010b; Biener et al. 2016; Eling and Schaper 2017), also because of the conceptual framework (see Cummins and Weiss 2013). Insurance companies provide three services to the insured: (1) risk-pooling and -bearing; (2) financial services; and (3) financial intermediation. We use net losses (i.e., paid losses plus additions to reserves) as our proxy for the risk pooling and financial service function. We use the smoothing procedure from Cummins and Xie (2008) to correct for the "errors in

\footnotetext{
${ }^{10}$ Given the relatively high homogeneity of our dataset (one country with relatively stable market conditions and regulatory frameworks over a long period of time), we favor DEA over Stochastic Frontier Analysis (SFA). In Appendix F, we also present the efficiency values for SFA using a translog stochastic input distance function following Eling and Luhnen (2010a). Comparing DEA and SFA confirms the relatively high homogeneity of our dataset, because the efficiency values are highly correlated. Most papers in insurance including those we cite for the overutilization (Cummins and Nini 2002) prefer DEA over SFA; see Kaffash et al. (2020).
} 
variables" problem in the loss output. The intermediation output is represented by the total investment value. ${ }^{11}$

\subsubsection{Input and input prices}

We follow the literature (e.g., Cummins and Weiss 2013) and use equity and debt capital (i.e., technical reserves) as well as labor as our input variables. As most of the insurers in our sample are not publicly traded, we use book values and apply regression analysis to estimate the capital prices for each firm individually.

For the price of equity, we adapt the approach suggested by Cummins and Weiss (2013) and estimate an OLS-regression equation with realized ROE $\left(R O E_{t}\right)$ as the dependent variable. To do so, we first calculate the ROE based on book values and, as the DEA demands positive input prices, delete all negative values and truncate the values at the $99 \%$ percentile to exclude extreme values. ${ }^{12}$ Second, we estimate the following OLS function:

$$
R O E_{t}=\beta_{0}+\beta_{1} S I Z E_{t}+\beta_{2} L E V_{t}+\beta_{3} D I V_{t}+\beta_{4} A S M_{t}+\varepsilon_{i, t}^{s},
$$

whereas SIZE is the natural logarithm of total assets, LEV (leverage) is the ratio of technical reserves divided by total assets, DIV (diversification) is the Herfindahl index of written gross premiums per business line and ASM (asset mix) is the Herfindahl index of the invested assets. For the regression results we refer to Table A.1 in Appendix A. Third, we use the estimated coefficients $\beta_{0}-\beta_{4}$ to calculate the price of equity for each insurer in our sample by inserting the specific firm values into the regression function. ${ }^{13}$

The price of debt capital is reflected in the premiums and dividend payments to policyholders (Cummins and Weiss 2013). As suggested by Cummins and Weiss (2013), the price of debt capital can be calculated as total investment income minus the estimated income from equity capital divided by the total amount of debt capital.

\footnotetext{
${ }^{11}$ The value-added approach may neglect other potential output dimensions. In Appendix G, we present efficiency values, where we add the Solvency I ratio as additional output representing differences in product quality. Overall, the results are in line with those presented in the main body of the analysis.

${ }^{12}$ We also check if truncating the values at 0 and the $95 \%$ percentile as well as the $5 \%$ and $95 \%$ percentile change our main results regarding the utilization of equity and labor. We do not find any significant changes of our results (see Appendix C).

${ }^{13}$ Recent studies (e.g., Cummins and Rubio-Misas 2006; Biener et al. 2016) use a stock index, for example the MSCI World or a country specific index, to approximate the capital costs of equity. Cummins and Xie (2008) compare the efficiency scores when using size and risk adjusted capital costs with efficiency scores when assigning the same capital costs to every company. The authors obtain for both approaches similar results. In our case, we need variation in the cost of capital, as we analyze the capital utilization, thus we prefer to use the individual price of equity. In a robustness check (see Appendix C), we use the 10-year average returns of the German stock index (DAX) and monthly German money market rates-our utilization results do not change significantly. One advantage of the approach we present here is that it also allows the inclusion of mutual firms in the estimation process, which otherwise might not be possible because of missing stock price data. Appendix $\mathrm{C}$ also presents various other robustness tests (e.g., including estimation of labor, impact of company age), which in general confirm the stability of the results presented in the main body of the paper.
} 
Table 2 Summary statistics for inputs, input prices, and outputs (1956-2019, 9899 firm years, 2019 real values)

\begin{tabular}{llllll}
\hline Variable & Unit & Mean & St. dev & Min & Max \\
\hline Output & & & & & \\
$\quad$ Losses incurred & TEUR & 135,319 & 356,337 & 1 & $5,754,754$ \\
$\quad$ Invested assets & TEUR & 462,776 & $1,504,837$ & 11 & $31,168,997$ \\
Input & & & & & \\
$\quad$ Equity capital & TEUR & 95,578 & 254,721 & 75 & $3,560,126$ \\
Debt capital & TEUR & 342,771 & $1,173,161$ & 1 & $20,758,740$ \\
$\quad$ Labor & Quantity & 697 & 1900 & 1 & 26,731 \\
Input prices & & & & & \\
Equity capital costs & $\%$ & 9.9 & 2.3 & 1.7 & 15.0 \\
$\quad$ Debt capital costs & $\%$ & 5.9 & 1.0 & 2.4 & 10.2 \\
Labor wages & EUR & 65,545 & 10,354 & 46,975 & 102,362 \\
\hline
\end{tabular}

To smooth the debt price, we apply the regression procedure: (1) delete all values, which are negative and greater than the $99 \%$ percentile; (2) use realized price of debt capital as the dependent variable in the regression model 0 above and estimate $\beta_{0}$ $-\beta_{4}$; and (3) use the estimated coefficients and calculate for each insurers the price of debt capital individually. We report the regression results in Table A.2 in Appendix A.

One key advantage of our data set is that we can obtain the number of employees directly from the Hoppenstedt Versicherungsjahrbuch. As price of labor, we use the yearly compensation per employee for the financial service industry, which includes the gross wage and social security contributions paid by the employer. To account for differences in regional wage levels, we use the compensation data of the federal state where the headquarters is located. Therefore, we assume that most employees work in the federal state of the headquarters. In Table 2, we present the summary statistics on the inputs, input prices, and outputs over the whole sample period.

\subsection{Utilization analysis}

To test our hypotheses, we first define the utilization for our inputs $i=\{$ labor, equity $\}$ as follows:

$$
U_{i, t}^{s}=\frac{I_{i, t}^{s}}{I_{i, t}^{s *}}-1,
$$

whereas $I_{i, t}^{S *}$ is the optimal amount of input $i$ for insurer $s(s=1,2, \ldots, S)$ at time $t$ and $I_{i, t}^{s}$ is the amount of input $i$ the insurer is actually using. Therefore, if $U_{i, t}^{s}>0$ 
insurer $s$ over-utilizes input $i$, and if $U_{i, t}^{s}<0$ insurer $s$ under-utilizes it (Cummins and Nini 2002). ${ }^{14}$

In order to investigate the impact (significant or insignificant) and direction (positive or negative) of a firm factor on input utilization, we estimate for each input $i$ the following year-fixed effects OLS regression model with the utilization ratio as our dependent variable and firm-specific values as independent variables:

$$
U_{i, t}^{s}=\beta_{0}+\beta X_{i, t}^{s}+\gamma T_{t}+\varepsilon_{i, t}^{s} .
$$

$X_{i, t}^{s}$ is the vector of firm characteristics. $T_{t}$ is the year fixed effects vector, $\beta$ and $\gamma$ are the parameters to be estimated.

To test our hypotheses regarding the utilization of labor, we measure size (SIZ) by the natural logarithm of total assets, business line diversification (DIV) by the Herfindahl index of 15 business lines, growth (GRO) by the one-year gross premium growth rate, distribution (DIS) by a direct insurer dummy (only available since 1992), and regional life quality (HDI) by a dummy variable indicating if the Human Development Index ${ }^{15}$ in the state of the insurer's headquarter is above the German average of the Human Development Index.

To analyze the findings from Cummins and Nini (2002) and to investigate the impact of firm factors on equity utilization, we add to our regression use of reinsurance (REI) measured by 1 minus the ratio of net to gross premiums, asset risk (AR) measured by the ratio of invested stock plus real estate to total investments, income risk (IR) measured by the three-year standard deviation of book-value return on equity, ${ }^{16}$ ownership (OWN) measured by a mutual dummy variable (equal to 1 if mutual, 0 if stock), and longer tailed business (LTB) measured by the ratio of loss reserves to incurred losses. ${ }^{17} \mathrm{We}$ also add these variables as controls in our labor utilization regression analysis.

Table 3 presents the summary statistics of the firm characteristics. We calculate the variance inflation factor and find no evidence for multicollinearity (all values $<2$ ). Moreover, we find no severe correlation between our variables (see Appendix B Table B). We only find larger Pearson correlation coefficients $(>0.4 ;<-0.4)$

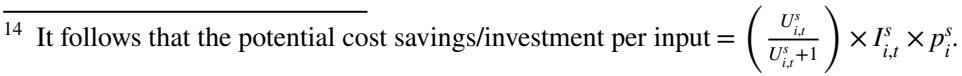

15 The Human Development Index combines life expectancy, education, and income level. It is available per state for the years 1990, 2000, 2010 and 2017. The federal states, which are above the German average do not change over the time horizon, except for North Rhine-Westfalia (NRW), which Human Development Index is above average for 1990 and 2000. Given these ambiguous results, we do not count NRW as a federal state with above average life quality.

${ }^{16}$ Cummins and Nini (2002) also use the three-year standard deviation of ROE as a measure of asymmetric information. Insurers with a high volatile income have higher information asymmetries than insurers with a less volatile, i.e., less risky, business. In the rationale of Cummins and Nini (2002), insurers with higher asymmetric information (i.e., higher values of the three-year standard deviation of book-value return on equity) use less equity capital. However, this directly contradicts their income risk hypothesis that insurer with higher income risk use more equity capital. They argue that the sign of this variable will indicate whether it measures asymmetric information or income risk. Cummins and Nini's (2002) findings support the asymmetric information hypothesis.

${ }^{17}$ Because of data limitation, we cannot test two other hypotheses on geographical diversification and business type (commercial vs. retail).
} 
Table 3 Summary statistics for firm characteristics (1959-2019, 8757 firm years)

\begin{tabular}{lccrr}
\hline Variable & Mean & St. dev & Min & Max \\
\hline Variables for labor hypotheses & & & & \\
$\quad$ Size (SIZ) & 18.44 & 1.92 & 12.37 & 24.26 \\
Business line diversification (DIV) & 0.58 & 0.33 & 0.11 & 1.00 \\
Premium growth (GRO) & 0.07 & 0.19 & -0.32 & 1.62 \\
Distribution (DIS) & 0.02 & 0.13 & 0.00 & 1.00 \\
Regional life quality (HDI) & 0.59 & 0.49 & 0.00 & 1.00 \\
Additional variables for equity utilization & & & -0.01 & 0.87 \\
Use of reinsurance (REI) & 0.31 & 0.21 & 0.00 & 1.00 \\
Asset risk (AR) & 0.46 & 0.24 & 0.00 & 0.66 \\
Income risk (IR) & 0.05 & 0.07 & 0.00 & 1.00 \\
Mutual dummy (OWN) & 0.33 & 0.47 & 0.00 & 4.42 \\
$\quad$ Longer tailed business (LTB) & 1.25 & 0.77 & & \\
\hline
\end{tabular}

Due to the calculation of the three-year standard deviation of book-value return on equity as a measure of the income risk (IR), the sample period is reduced to 1959-2019

To exclude extreme values, we winsorize the premium growth (GRO), the reinsurance use (REI), the ROE before the calculation of the standard deviation and the longer tailed business (LTB) to the 1 and $99 \%$ percentile

Our results regarding the utilization regressions are robust with respect to the choice of the percentiles In Appendix C (see Tables C.5 and C.6) we present the results when winsorizing at the 5 and $95 \%$ percentile

for the diversification and size variables, in other words, larger insurers tend to be more diversified.

Due to the calculation of the three-year standard deviation of book-value return on equity as a measure of the income risk (IR), the sample period is reduced to 1959-2019. To exclude extreme values, we winsorize the premium growth (GRO), the reinsurance use (REI), the ROE before the calculation of the standard deviation and the longer tailed business (LTB) to the $1 \%$ and $99 \%$ percentile. Our results regarding the utilization regressions are robust with respect to the choice of the percentiles. In Appendix C (see Tables C.5 and C.6) we present the results when winsorizing at the $5 \%$ and $95 \%$ percentile.

\section{Empirical results}

\subsection{Efficiency levels and utilization of inputs}

In Fig. 2 we present the average period pure technical efficiency (PTE), allocative efficiency (AE), and cost efficiency (CE) scores (assuming variable return to scale) for the total sample period of 1956-2019 and for 9899 firm years. Over the whole sample, PTE is on average 0.82, ranging from 0.72 in 1972 to 0.88 in 2003. Our results are in line with Luhnen (2009), who reports an average PTE of 0.80 for the German p/c insurance industry for the sample period of 1995-2006, but they are 


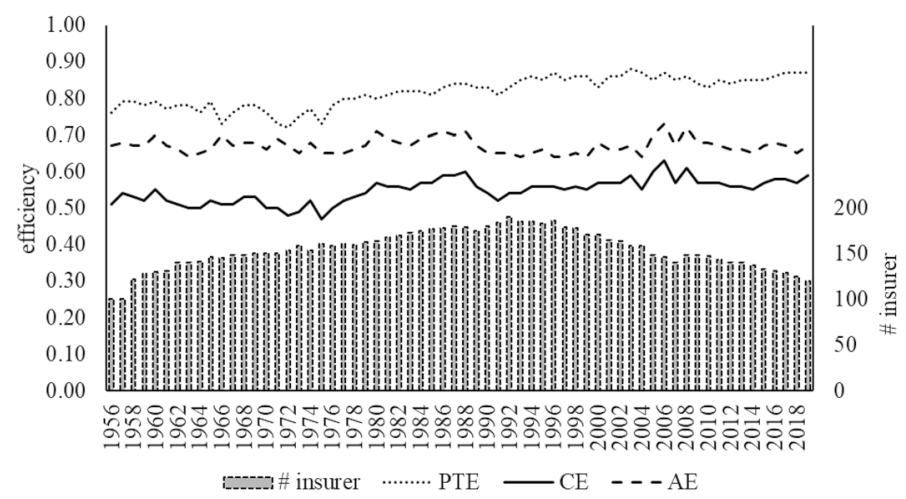

Fig. 2 Development of DEA efficiency scores over time

slightly higher than those reported by Mahlberg and Url (2010), who arrived at an average PTE of 0.72 for German insurance groups between 1991 and 2006. The PTE values are also comparable to Hussels and Ward's (2007) results of 0.76 for the German life insurance industry.

The cost efficiency (CE) values range from 0.47 in 1975 and 0.63 in 2006, with an average of 0.55 over the entire sample period. Our results are slightly higher than those of Luhnen (2009), who identifies an average CE score of 0.48 . They are considerably higher than the average $\mathrm{CE}$ score of 0.40 reported by Mahlberg and Url (2010). For the German life insurance industry, Hussels and Ward (2007) and Trigo-Gamarra and Growitsch (2010) find an average CE score of 0.56 and 0.48 for the time period of 1991-2002 and 1997-2005, respectively. Recently, we see an increase in $\mathrm{CE}$ which might be explained by increasing competitive pressure due to the use of comparison platforms.

For the duration of our sample period the PTE values are quite high, implying that the German p/c insurers adapt to the state-of-the-art technology. However, some insurers always seem to use the technology more efficiently; it seems impossible to close that gap. The PTE scores have slightly increased since the mid-1970s. This may be attributed to the increased use of computers, which offer every company the same possibilities and access to the start-of-the-art technology. Before that, insurers employing the most skilled experts (being a limited resource) may have had a competitive advantage.

The main driver for the low CE values is the allocative inefficiency; in other words, insurers do not choose the best (cost-minimizing) input combination. Based on the $\mathrm{CE}$ results, we report in Fig. 3 the utilization of labor and equity per year over the entire sample period. Insurers use too much labor input, with an average of $83 \%$, which fluctuates between 58 and $132 \%$, but it seems that there is no general trend in the utilization of labor. The average utilization of equity is around $10 \%$ and falls between $-29 \%$ and $58 \%$. German p/c insurers have used to less equity capital in the 1960s and 1980s, thus, cost efficient insurers have used more equity and less labor in these periods. Moreover, we observe an increase of the equity over-utilization in the mid-1990s. This may be explained by the deregulation in 1994. Until then, German 


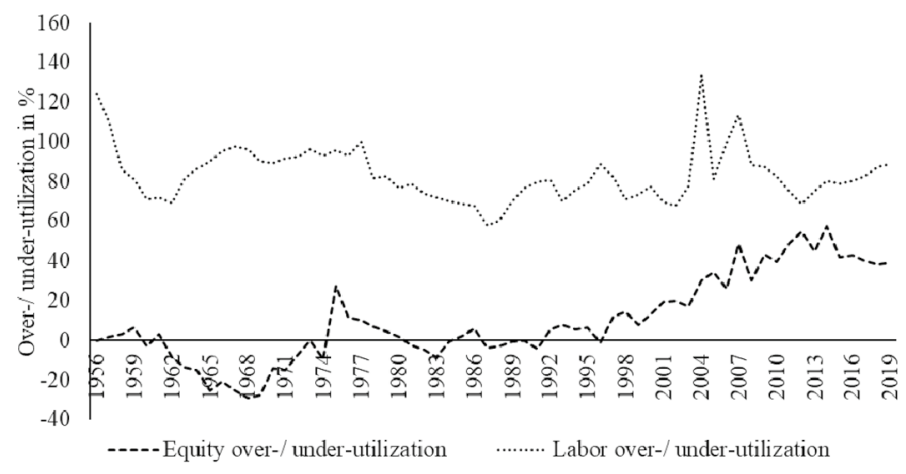

Fig. 3 Development of equity and labor over-/ under-utilization over time

$\mathrm{p} / \mathrm{c}$ insurers' prices, products and operations had been strictly regulated (Hussels and Ward 2007). As a result, the German p/c insurance sector had no need for profound efficiency improvements as the competitive pressure was limited. Leibenstein (1966) argues that competition increases the motivation of staff and firms to be more efficient. In situation with lighter competition, they prefer not to put all their efforts and resources into efficiency maximization. Maybe under the new competitive pressure, some insurers started to optimize (minimize) their use of equity capital. If this was true, the overall efficiency should have decreased. Therefore, we think some insurers may have increased their equity to show solvency or to grow their business (in line with the premium growth hypothesis, see Cummins and Nini 2002). However, the additional capital has not severely influenced their efficiency.

When analyzing the drivers of cost efficiency, we find that the cost inefficiency (1-CE, the cost saving potential) is mainly driven by the inefficient use of labor over the entire sample period (Fig. 4), whereas the inefficient use of equity is slightly increasing. In summary, we confirm our first hypothesis that the labor input offers a high potential for improvement. We do not observe that the utilization of labor increases over the past years. Instead, we find rising equity levels, which so far have no large impact on insurers' efficiency. One possible explanation for the rising equity utilization might the anticipation of the Solvency II introduction in 2016 and the increase in capital following the stock market crisis in 2002/2003 and the financial crisis in 2008 .

\subsection{Labor utilization}

We report the regression results for labor utilization in Table 4 and the development over time in Table 5. Most of our hypotheses are confirmed by our regression results.

Size-In line with studies from the manufacturing industry (e.g., van Ark and Monnikhof 1996; Leung et al. 2008) and research on insurance efficiency (e.g., Cummins and Zi 1998; Cummins and Rubio-Misas 2006; Eling and Luhnen 2010a), we expect a negative relation between firm size and labor utilization. The regression 


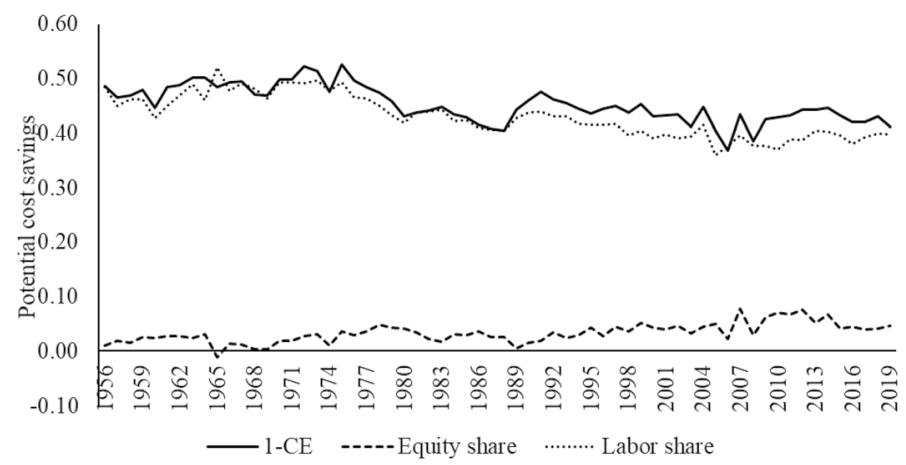

Fig. 4 Potential cost savings per input

results confirm our hypothesis 2 as shown in Table 4 and they are consistent over time (Table 5). For the years 2010 through 2019 we cannot confirm this inverse relationship. However, the growth variable seems to explain most of the labor utilization, which might offset the influence of size.

Diversification of business lines-Hypothesis 3 (specialized insurers use less labor) is confirmed by our analysis (Table 4). As we have shown, labor is the driver of cost inefficiency, thus, we can confirm Luhnen's (2009) results showing that specialized German p/c insurers are more efficient. Our results contradict the conglomeration theory (Biener et al. 2016) that diversified insurers can profit from synergy effects along their value chain. The results are consistent over time (Table 5), but not for 2010-2019.

Premium growth-We can confirm that insurers with higher growth rates use too much labor (hypothesis 4). The results are in line with Luhnen (2009), who emphasizes that insurers with higher growth rates are less cost efficient. Our belief that growing insurers use first their existing employees is only confirmed for the years 1980-1989 (Table 5).

Distribution-As direct insurers should have fewer complex products and service offerings, we expect direct insurers to use less labor. However, we cannot confirm hypothesis 5 (Table 4). Our results are not in line with Luhnen (2009), whose results show that direct insurers are more cost efficient than agent insurers. Our results hold for both the period 1990-1999 and the more recent period 2010-2019 (Table 5). The first results might be explained by the transformation from agent insurers to direct insurers in the middle of the 1990s. Thus, the first direct insurers may have still used the whole infrastructure of agent insurers. Also direct insurers entering the market more recently have not yet been able to use labor more efficiently, maybe also because of regulatory requirements, which increase the required number of people. ${ }^{18}$

\footnotetext{
18 No direct insurers existed prior to 1990. In Appendix E we compare cost efficiency values between direct and non-direct insurers. The analysis shows that there are only efficiency differences between insurers with different distribution channels in the 1990s. The results become less significant if we use the estimated labor numbers (ratio of operating and labor expenses) to increase the number of direct insurers as sometimes labor book values are not given for direct insurers. Additionally, we considered
} 
Table 4 Regression results for labor utilization

\begin{tabular}{|c|c|c|}
\hline Variable & Expected sign & Coefficients \\
\hline \multicolumn{3}{|l|}{ Main variables } \\
\hline Intercept & & $\begin{array}{l}20.426 * * * \\
(1.972)\end{array}$ \\
\hline Size (SIZ) & - & $\begin{array}{l}-1.070^{* * *} \\
(0.082)\end{array}$ \\
\hline Business line diversification (DIV) & - & $\begin{array}{l}-1.500^{* * *} \\
(0.421)\end{array}$ \\
\hline Premium growth (GRO) & + & $\begin{array}{l}2.246^{* * *} \\
(0.634)\end{array}$ \\
\hline Distribution (DIS) & - & $\begin{array}{l}3.838 * * * \\
(0.908)\end{array}$ \\
\hline Regional life quality (HDI) & - & $\begin{array}{l}-0.614^{* * *} \\
(0.243)\end{array}$ \\
\hline \multicolumn{3}{|l|}{ Control variables } \\
\hline Use of reinsurance (REI) & & $\begin{array}{l}6.354 * * * \\
(0.624)\end{array}$ \\
\hline Asset risk (AR) & & $\begin{array}{l}-1.315^{* *} \\
(0.644)\end{array}$ \\
\hline Income risk (IR) & & $\begin{array}{l}1.187 \\
(1.774)\end{array}$ \\
\hline Mutual dummy (OWN) & & $\begin{array}{l}1.264 * * * \\
(0.262)\end{array}$ \\
\hline Longer tailed business (LTB) & & $\begin{array}{l}-0.901^{* * *} \\
(0.172)\end{array}$ \\
\hline Year fixed effects & & YES \\
\hline Sample size & & 8757 \\
\hline Adjusted $\mathrm{R}^{2}$ & & 0.122 \\
\hline
\end{tabular}

$* * *, * *$, and $*$ represent significance at the 1,5 , and $10 \%$ levels, respectively

As the dependent variable we use the ratio of actual-to-optimal labor minus one

Standard errors are presented in parentheses

Regional factor-We argue that insurers in states with a better quality of life (measured by the Human Development Index) should have it easier to find the best employees, because the labor supply might be higher there. Another effect could be that employees in regions with a better quality of life are more productive and

Footnote 18 (continued)

meta- and cross-efficient-frontiers (e.g., Cummins et al. 1999), but the results are not meaningful due to the sample size of direct insurers. 


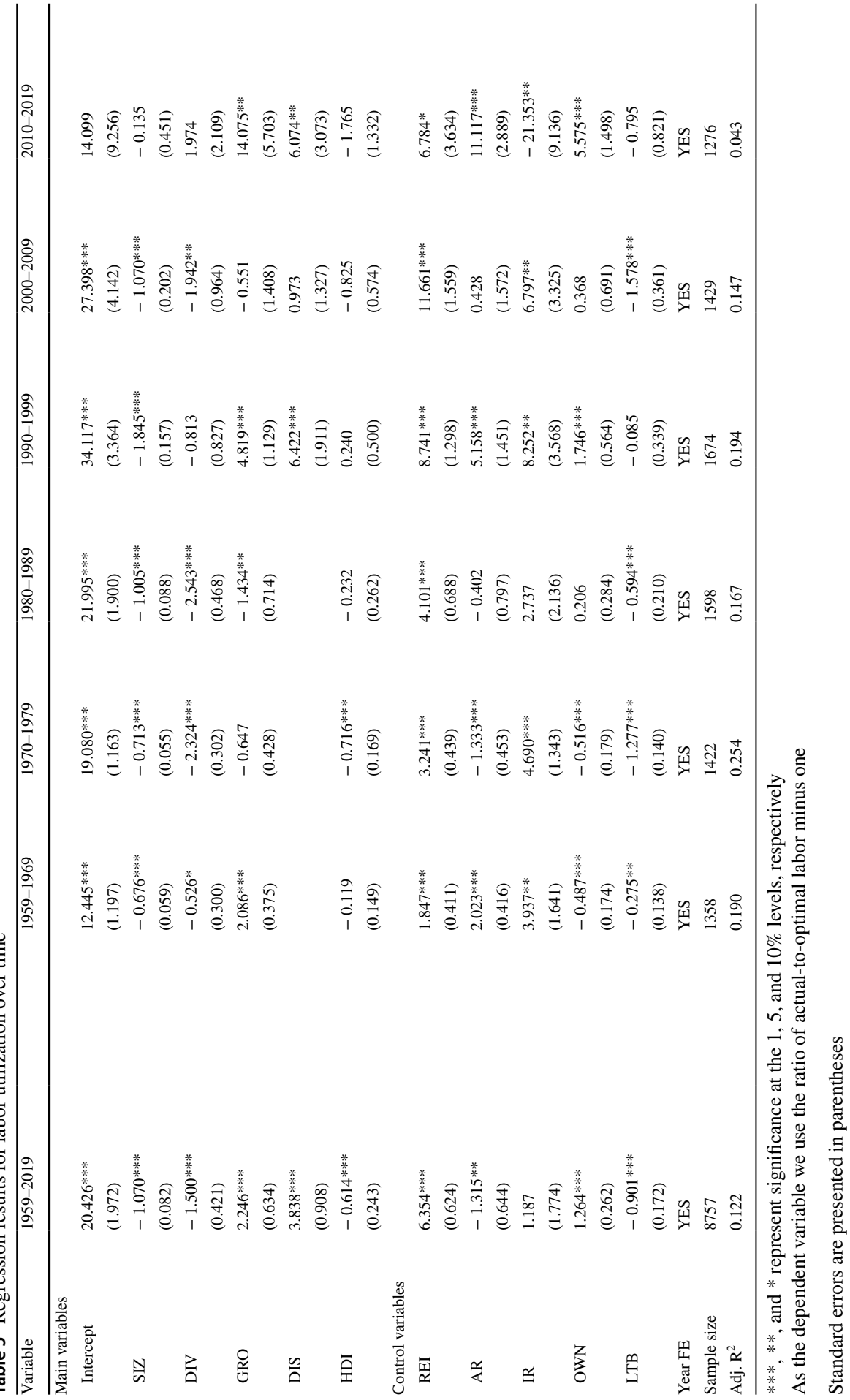


motivated as they are more afraid of being replaced (which is easier for insurers because of the higher labor supply). Our results confirm our assumption (Table 4).

With respect to our control variables, we find that insurers with more reinsurance use and mutuals use ceteris paribus more labor. Insurers with longer tailed business and higher asset risk significantly use less labor. These results are rather exploratory as we had no prior assumption regarding their impact on labor utilization.

\subsection{Equity utilization}

We briefly analyze the hypotheses by Cummins and Nini (2002) and present the results on the impact of the firm characteristics on equity utilization in Table 6. In line with Cummins and Nini's (2002) hypotheses, we can confirm a negative relationship for firm size and long tailed business. However, the relation between size and equity utilization has inverted in later periods (Table 7). This may be explained by the introduction of Solvency I and II, which may have led insurers to accumulate capital. Larger insurers may have an easier access to the capital market and could raise more capital to signal stronger solvency. We confirm their findings with respect to income risk. Thus, the income risk variable seems to capture the asymmetric information between managers and investors (Cummins and Nini 2002). We find a significant positive relationship for asset risk. Moreover, we can confirm Cummins and Nini's (2002) hypotheses for diversification (diversified insurers use less equity capital) and for premium growth—neither hypothesis could be confirmed by Cummins and Nini (2002).

Over the entire sample period, we cannot confirm that mutual insurers use less equity capital; all we find is a significant negative relationship for the period 1959-1969 (Table 7). In all other periods, mutual insurers use more equity capital than stock insurers. Our results are in line with the finding that mutual insurers may have limited access to the capital market and therefore save up capital. Moreover, our findings contradict that owners of mutual insurers try to mitigate the moral hazard of insurance managers (to resolve the owner-manager conflict) by decreasing the amount of equity. In contrast to Cummins and Nini (2002), our measure of reinsurance use is positively correlated with the use of equity. This can be explained by the fact that we use net values in our analysis. ${ }^{19}$ Overall, our results reinforce the results documented for the U.S. for a significant longer time period and the German insurance market.

\footnotetext{
19 For example, let us consider two insurers A and B with the same net invested assets. Both insurers have the same gross technical reserves, but insurer B uses more reinsurance. In consequence, the net reserves of insurer $B$ are lower. Using net balance sheet data, we know that approximately: equity ${ }_{A}+$ net

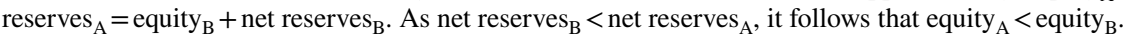


Table 6 Regression results for equity utilization

\begin{tabular}{|c|c|c|}
\hline Variable & $\begin{array}{l}\text { Expected results Cummins and Nini } \\
(2002)\end{array}$ & Coefficients \\
\hline Intercept & & $\begin{array}{l}0.267 * \\
(0.145)\end{array}$ \\
\hline Size (SIZ) & - & $\begin{array}{l}-0.010^{*} \\
(0.006)\end{array}$ \\
\hline Business line diversification (DIV) & + & $\begin{array}{l}0.253 * * * \\
(0.031)\end{array}$ \\
\hline Premium growth (GRO) & + & $\begin{array}{l}0.259 * * * \\
(0.046)\end{array}$ \\
\hline Reinsurance use (REI) & - & $\begin{array}{l}0.906 * * * \\
(0.046)\end{array}$ \\
\hline Asset risk (AR) & + & $\begin{array}{l}0.166^{* * * *} \\
(0.047)\end{array}$ \\
\hline Income risk (IR) & Ambiguous & $\begin{array}{l}-1.226^{* * *} \\
(0.130)\end{array}$ \\
\hline Mutual dummy (OWN) & Ambiguous & $\begin{array}{l}0.047 * * \\
(0.019)\end{array}$ \\
\hline Longer tailed business (LTB) & - & $\begin{array}{l}-0.079 * * * \\
(0.013)\end{array}$ \\
\hline Year fixed effects & & YES \\
\hline Sample size & & 8757 \\
\hline Adjusted $\mathrm{R}^{2}$ & & 0.105 \\
\hline
\end{tabular}

$* * *, * *$, and * represent significance at the 1,5 , and $10 \%$ levels, respectively

As the dependent variable we use the ratio of actual-to-optimal equity minus one

Standard errors are presented in parentheses

\section{Conclusion}

Scholars have investigated the productivity and efficiency of the insurance industry, but only Cummins and Nini (2002) have analyzed the utilization of input factors and firm characteristics driving the usage of equity. In this paper we quantify the productivity and efficiency in the German p/c insurance industry from 1956 to 2019. We use DEA analysis to study the utilization of the inputs labor and equity and use OLS regression to understand which firm characteristics influence labor and capital utilization. The average pure technical efficiency is 0.82 for our entire sample period. The average cost efficiency value of 0.55 is much lower and driven by the fact that German $\mathrm{p} / \mathrm{c}$ insurers are not choosing the cost-minimizing input combination. We find that the labor input is the main driver of cost inefficiency and offers the most room for improvement. In recent years the inefficiency resulting from the labor input has decreased whilst (?) capital levels have increased, which might become another source of inefficiency. 


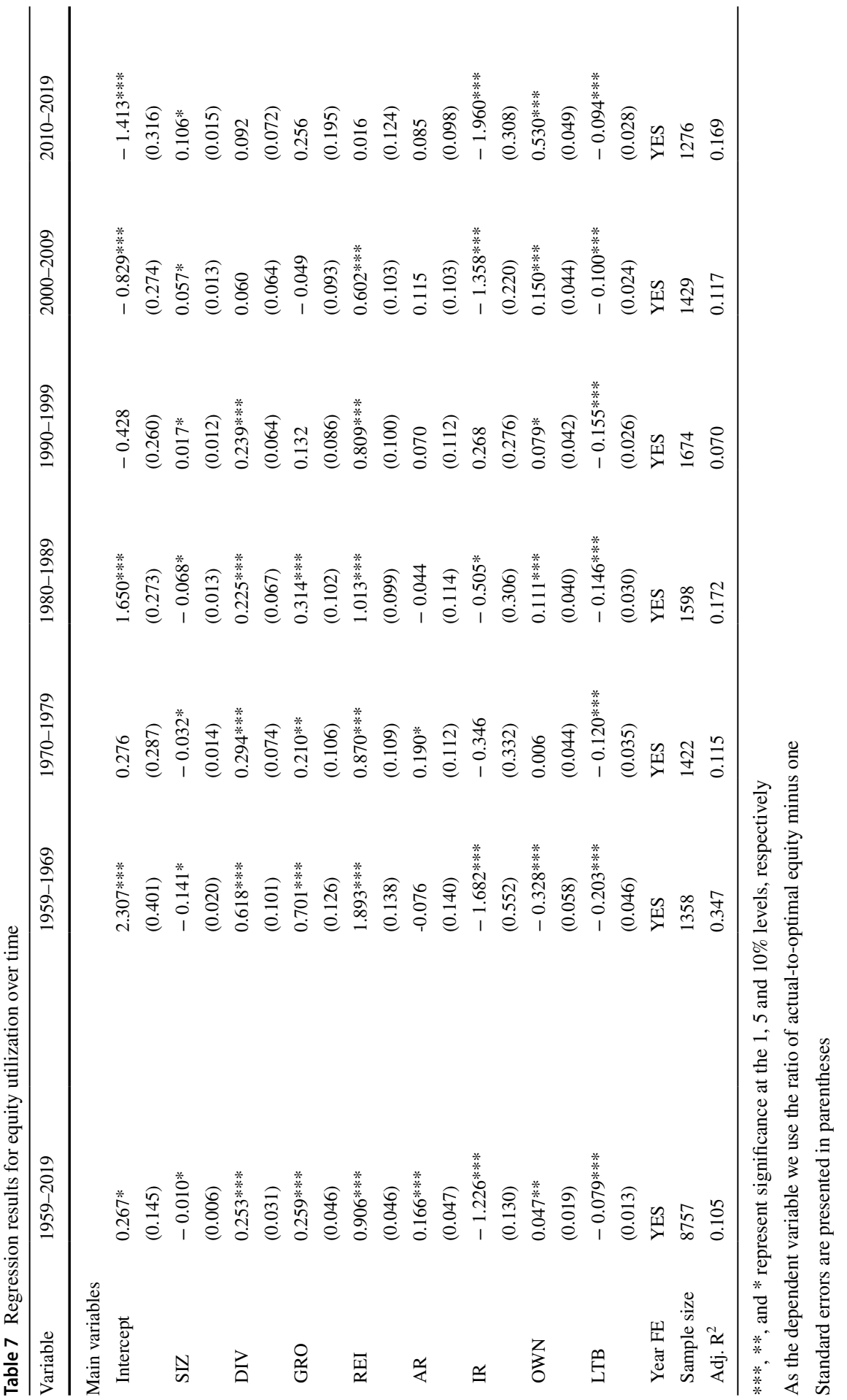


In our analysis of firm characteristics driving the utilization of labor, we find support that larger insurers use less labor. There is evidence that more specialized insurers use labor more efficiently. Regarding premium growth, we find that growing insurers use more labor. Thus, insurers that grow not only invest in costly marketing campaigns, which increases the operating costs (Luhnen 2009), but also in new employees. We do not find support for our hypothesis that direct insurers use less labor. The results may be driven by former non-direct insurers which have become direct insurers and still use the prior labor force. These results may change with more new direct insurers entering the market which can build their infrastructure from scratch and therefore use a smaller labor input. Insurers in regions with better quality of life are found to use less labor. We hypothesized that quality of life could be an indicator for a larger labor supply as more people want to live in those regions. As a result, insurers in those regions can hire the most productive employees. Therefore, they can use less labor.

We confirm most of the hypotheses from Cummins and Nini (2002) with respect to firm factors influencing the utilization of equity. We find support for the financial distress hypothesis in the size, diversification and asset risk variables. Contrary to Cummins and Nini (2002) we find that German mutual p/c insurers use more equity capital compared to stock insurers. We interpret this finding that mutual insurers pile up equity capital as they have limited access to the capital market. Thus, the present owner-manager conflict at mutual insurers is not resolved by decreasing equity capital. In line with Cummins and Nini (2002), we find that insurers with longer tailed business and higher information asymmetries use less equity capital to resolve the manager-policyholders and manager-investor conflict, respectively. Furthermore, our results show that growing insurers stack up capital that they do not have to raise expensive capital later. Our results complement the work from Cummins and Nini (2002) as we focus on the utilization of labor, which is the largest component of cost inefficiency.

The findings have implications for insurance managers and policymakers. Our results show that there is a large potential in the insurance industry to reduce the amount of labor to become more efficient. But, due to the strong German labor laws, unions as well as work councils reducing the workforce might be complicated for insurers and often only undertaken by retirement. If technology takes over more and more tasks, the utilization of labor may increase in companies that cannot flexibly reduce its workforce. In contrary, new competitors that can use technology from the beginning can optimize their utilization of labor and therefore have a competitive advantage. Moreover, as German p/c insurers do not only operate in Germany, they may have a competitive disadvantage compared to insurers in countries, in which technology is used more often while having more liberal labor laws. In addition, policymakers must find a solution how to deal with those employees that may get replaced by technology. This development might have a large impact on the cohesion of society; ideas of societal involvement must be developed.

We also note that our analysis is purely based on firms' production efficiency. In reality, policymakers and management may have broader considerations than just the efficiency of production. A government may see the employment rate or employees' rights as no less important than insurance companies' efficient use of 
capital. Insurance companies may take policyholders' privacy and ethical concerns into account and therefore limit their adoption of modern technology (e.g., in underwriting) to maintain good long-term reputation. We also note the power of unions in Germany, which might favor well paid and sustainable jobs over the efficient use of input factors.

While our paper certainly cannot answer all questions on the impact of technology and the interaction between labor and capital, our analysis might provide avenues for future research in various directions. For example, the impact of the utilization on revenue and profit efficiency could be further analyzed. Moreover, it could be valuable to distinguish between new direct insurers and transformed direct insurers. So far, the sample size of new direct insurers is still limited. Future data may make the analysis more robust. Furthermore, meta- and cross-frontier analysis could help to understand if non-direct and direct insurers use the same technology or if they should be analyzed separately. Additionally, it would be very helpful to distinguish between various job positions to further analyze each positions' utilization. Based on that one could make more detailed predictions on the future of labor in the insurance industry.

In general, a more detailed analysis on the interaction between labor and capital usage and how this is affected by the use of technology would be very useful, but goes beyond what can be done with the current data at hand. It might, for example, be interesting to link our results to research results on inefficiency during adjustment processes in transition periods (Fandel and Lorth 2010). To investigate if more technological advanced insurers use their labor more efficiently, it would be helpful to have information or data on the insurers' technological development, for example numbers on insurers' spending into technology. However, this information is not part the book values we analyze here. Alternatively, the approach by Bohnert et al. (2019) to use advanced text mining methods on annual reports of insurance companies could be a way to determine the digital activities. The annual report data we consider here is not as detailed on the description of the business and technological development. Moreover, a survey among management could help to determine insurers' technological maturity. However, the self-assessments may be hard to compare between insurers, and historical information does not exist.

Moreover, it could be interesting to analyze the utilization of the life insurance industry and to compare our results within a European context. For example, it could be insightful if insurers in countries with more liberal labor laws (e.g., Switzerland or U.K.) use less labor and if this leads to a competitive advantage in terms of productivity and efficiency. Furthermore, it could be interesting to compare our results with the banking sector and the manufacturing industry to see how labor and capital are used. With future data the impact of recent technological developments on insurers efficiency could be analyzed in more detail.

\section{Appendix A: Equity and debt capital costs regression results}

See Tables A.1, A.2, C.1, C.2, C.3, C.4, C.7, D.1, E.1, E.2. 
Table A.1 Equity capital cost estimation OLS regression results $(n=9899)$
Table A.2 Debt capital cost estimation OLS regression results $(n=9899)$

\begin{tabular}{ll}
\hline Variable & Realized book ROE \\
\hline SIZE_logarithm of total assets & $0.006^{* * *}$ \\
& $(0.001)$ \\
LEV—technical reserves/total assets & $0.064^{* * *}$ \\
& $(0.006)$ \\
DIV—Herfindahl index of written gross pre- & $0.013^{* * *}$ \\
miums per business line & $(0.003)$ \\
& $-0.040^{* * *}$ \\
AM-Herfindahl index of invested assets & $(0.008)$ \\
& $-0.039^{* * *}$ \\
Constant & $(0.013)$ \\
\end{tabular}

$* * *, * *$, and $*$ represent significance at the 1,5 , and $10 \%$ levels, respectively

As the dependent variable we use realized ROE (net income/equity capital)

We delete all negative capital prices and exclude extreme values above the $99 \%$ percentile

Standard errors are presented in parentheses

\begin{tabular}{ll}
\hline Variable & $\begin{array}{l}\text { Realized price } \\
\text { of debt capital }\end{array}$ \\
\hline SIZE—-logarithm of total assets & $0.004^{* * *}$ \\
& $(0.000)$ \\
LEV—technical reserves/total assets & $-0.060^{* * *}$ \\
& $(0.002)$ \\
DIV—Herfindahl index of written gross premiums & $0.008^{* * *}$ \\
per business line & $(0.001)$ \\
& $-0.010^{* * *}$ \\
AM—Herfindahl index of invested assets & $(0.003)$ \\
& $-0.016^{* * *}$ \\
Constant & $(0.005)$
\end{tabular}

$* * *, * *$, and * represent significance at the 1,5 , and $10 \%$ levels, respectively

As the dependent variable we calculate the realized debt capital price as suggested by Cummins and Weiss (2013) as follows: (total investment income-investment income due to equity)/debt capital

We delete all negative capital prices and exclude extreme values above the $99 \%$ percentile

Standard errors are presented in parentheses 


\section{Appendix B: Correlation matrix}

Table B Pearson correlation and variance inflation factors (VIF) for regression regressors (1959-2019, 8757 firm years)

\begin{tabular}{llllllllllll}
\hline Variable & SIZ & DIV & GRO & DIS & HDI & REI & AR & IR & OWN & LTB & VIF \\
\hline SIZ & 1.00 & -0.44 & -0.12 & 0.06 & 0.00 & -0.21 & -0.04 & 0.04 & -0.09 & 0.39 & 1.75 \\
DIV & & 1.00 & 0.06 & 0.00 & 0.09 & -0.17 & 0.01 & -0.03 & 0.00 & -0.09 & 1.43 \\
GRO & & & 1.00 & 0.04 & 0.01 & 0.02 & 0.01 & 0.01 & -0.06 & -0.09 & 1.02 \\
DIS & & & & 1.00 & -0.02 & -0.04 & -0.16 & 0.07 & -0.09 & 0.01 & 1.04 \\
HDI & & & & & 1.00 & 0.02 & 0.01 & 0.05 & -0.18 & 0.00 & 1.05 \\
REI & & & & & & 1.00 & 0.05 & -0.03 & -0.12 & 0.06 & 1.24 \\
AR & & & & & & & 1.00 & -0.16 & 0.13 & -0.10 & 1.07 \\
IR & & & & & & & & 1.00 & -0.07 & 0.06 & 1.04 \\
OWN & & & & & & & & & 1.00 & -0.15 & 1.12 \\
LTB & & & & & & & & & & 1.00 & 1.27 \\
\hline
\end{tabular}

\section{Appendix C: Robustness tests}




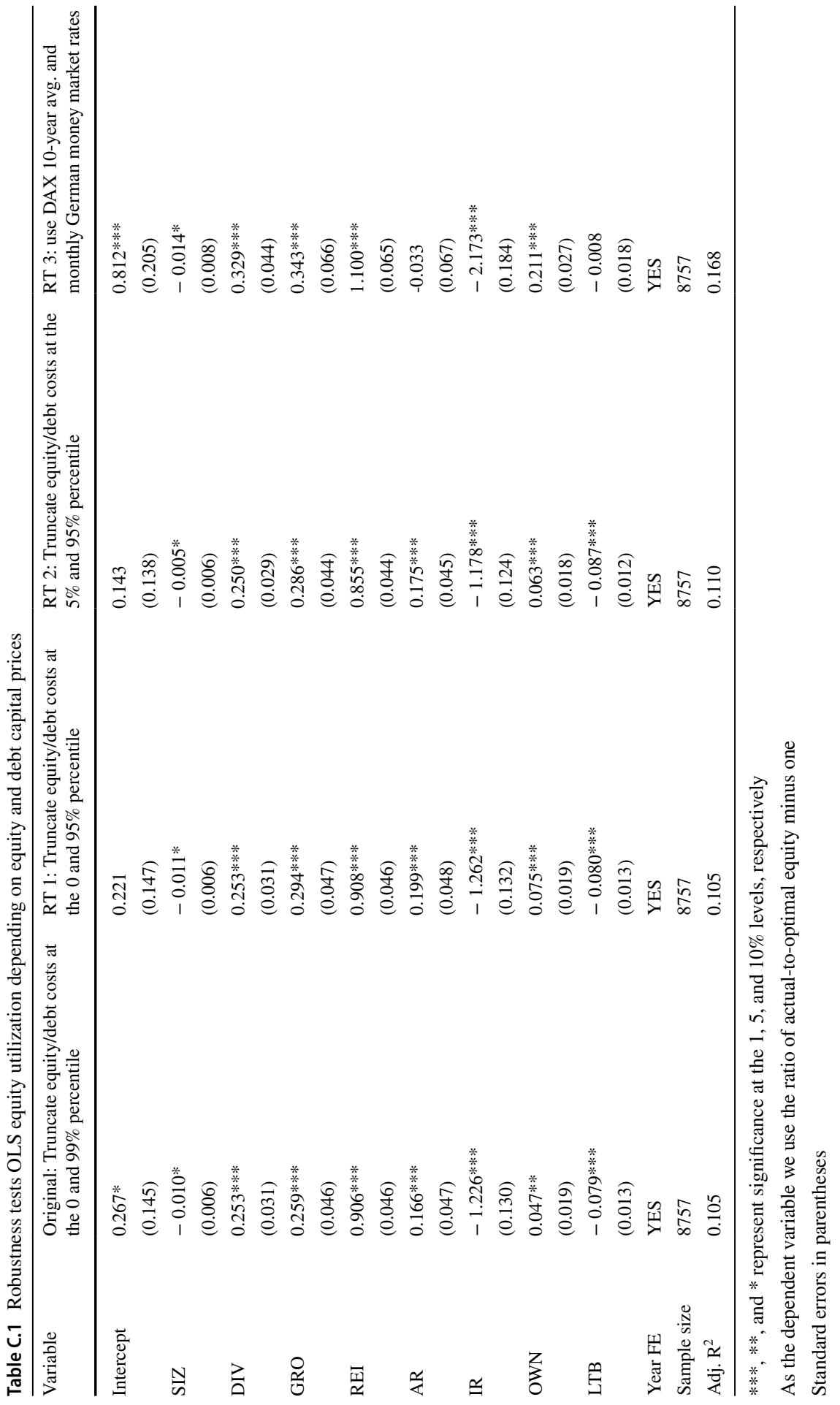


Table C.2 Robustness tests OLS labor utilization depending on equity and debt capital prices

\begin{tabular}{|c|c|c|c|c|}
\hline Variable & Original & RT 1 & RT 2 & RT 3 \\
\hline Intercept & $\begin{array}{l}20.426 * * * \\
(1.972)\end{array}$ & $\begin{array}{l}21.012 * * * \\
(2.078)\end{array}$ & $\begin{array}{l}21.606^{* * * *} \\
(2.219)\end{array}$ & $\begin{array}{l}20.699 * * * \\
(1.526)\end{array}$ \\
\hline SIZ & $\begin{array}{l}-1.070^{* * *} \\
(0.082)\end{array}$ & $\begin{array}{l}-1.098 * * * \\
(0.086)\end{array}$ & $\begin{array}{l}-1.130 * * * \\
(0.092)\end{array}$ & $\begin{array}{l}-1.111^{* * *} \\
(0.063)\end{array}$ \\
\hline DIV & $\begin{array}{l}-1.500 * * * \\
(0.421)\end{array}$ & $\begin{array}{l}-1.289 * * * \\
(0.444)\end{array}$ & $\begin{array}{l}-1.205^{* *} \\
(0.474)\end{array}$ & $\begin{array}{l}-2.220 \text { *** } \\
(0.326)\end{array}$ \\
\hline GRO & $\begin{array}{l}2.246 * * * \\
(0.634)\end{array}$ & $\begin{array}{l}2.215 * * * \\
(0.668)\end{array}$ & $\begin{array}{l}2.220 * * * \\
(0.713)\end{array}$ & $\begin{array}{l}1.779 * * * \\
(0.491)\end{array}$ \\
\hline DIS & $\begin{array}{l}3.838 * * * \\
(0.908)\end{array}$ & $\begin{array}{l}4.144 * * * \\
(0.957)\end{array}$ & $\begin{array}{l}4.047 * * * \\
(1.022)\end{array}$ & $\begin{array}{l}4.772 * * * \\
(0.703)\end{array}$ \\
\hline HDI & $\begin{array}{l}-0.614 * * * \\
(0.243)\end{array}$ & $\begin{array}{l}-0.668 * * * \\
(0.256)\end{array}$ & $\begin{array}{l}-0.725 * * * \\
(0.273)\end{array}$ & $\begin{array}{l}-0.120 \\
(0.188)\end{array}$ \\
\hline REI & $\begin{array}{l}6.354 * * * \\
(0.624)\end{array}$ & $\begin{array}{l}6.563 * * * \\
(0.657)\end{array}$ & $\begin{array}{l}6.441 * * * \\
(0.702)\end{array}$ & $\begin{array}{l}6.535 * * * \\
(0.483)\end{array}$ \\
\hline $\mathrm{AR}$ & $\begin{array}{l}-1.315^{* *} \\
(0.644)\end{array}$ & $\begin{array}{l}-1.881 * * * \\
(0.679)\end{array}$ & $\begin{array}{l}-2.185 * * * \\
(0.725)\end{array}$ & $\begin{array}{l}0.697 \\
(0.499)\end{array}$ \\
\hline IR & $\begin{array}{l}1.187 \\
(1.774)\end{array}$ & $\begin{array}{l}0.404 \\
(1.870)\end{array}$ & $\begin{array}{l}-0.055 \\
(1.997)\end{array}$ & $\begin{array}{l}5.660 * * * \\
(1.373)\end{array}$ \\
\hline OWN & $\begin{array}{l}1.264 * * * \\
(0.262)\end{array}$ & $\begin{array}{l}1.351 * * * \\
(0.276)\end{array}$ & $\begin{array}{l}1.476 * * * \\
(0.295)\end{array}$ & $\begin{array}{l}0.331 \\
(0.203)\end{array}$ \\
\hline LTB & $\begin{array}{l}-0.901 * * * \\
(0.172)\end{array}$ & $\begin{array}{l}-0.828 * * * \\
(0.181)\end{array}$ & $\begin{array}{l}-0.664 * * * \\
(0.193)\end{array}$ & $\begin{array}{l}-1.580^{* * * *} \\
(0.133)\end{array}$ \\
\hline Year FE & YES & YES & YES & YES \\
\hline Sample size & 8757 & 8757 & 8757 & 8757 \\
\hline Adj. $\mathrm{R}^{2}$ & 0.122 & 0.120 & 0.110 & 0.215 \\
\hline
\end{tabular}

$* * *, * *$, and $*$ represent significance at the 1,5 , and $10 \%$ levels, respectively

As the dependent variable we use the ratio of actual-to-optimal labor minus one

Standard errors in parentheses 


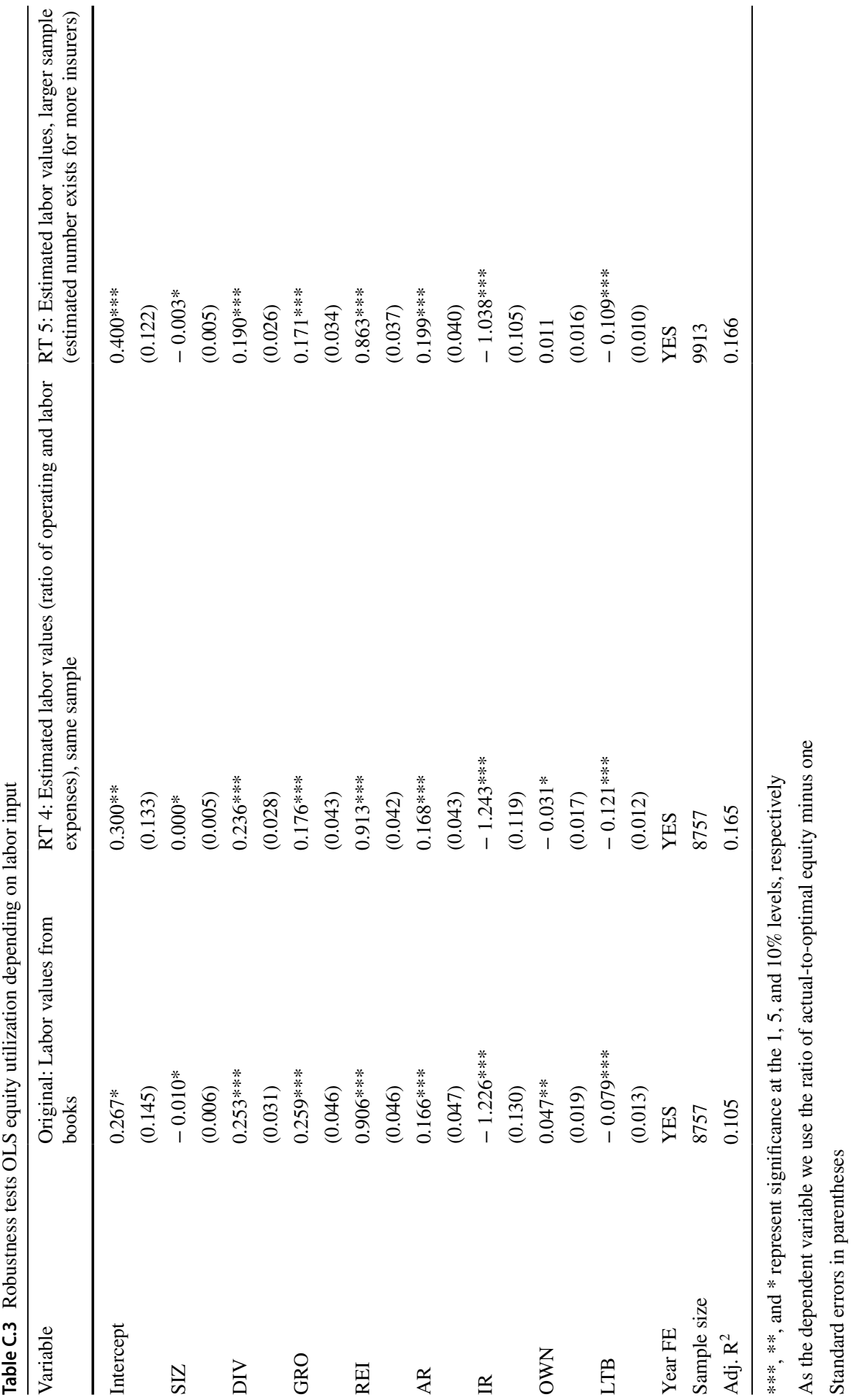


Table C.4 Robustness tests OLS labor utilization depending on labor input

\begin{tabular}{|c|c|c|c|}
\hline Variable & Original & RT 4 & RT 5 \\
\hline Intercept & $\begin{array}{l}20.426 * * * \\
(1.972)\end{array}$ & $\begin{array}{l}39.057 * * * \\
(2.811)\end{array}$ & $\begin{array}{l}42.491 * * * \\
(2.679)\end{array}$ \\
\hline SIZ & $\begin{array}{l}-1.070 * * * \\
(0.082)\end{array}$ & $\begin{array}{l}-1.664 * * * \\
(0.116)\end{array}$ & $\begin{array}{l}-1.861 * * * \\
(0.111)\end{array}$ \\
\hline DIV & $\begin{array}{l}-1.500^{* * *} \\
(0.421)\end{array}$ & $\begin{array}{l}-2.343 * * * \\
(0.600)\end{array}$ & $\begin{array}{l}-2.125^{* * *} \\
(0.575)\end{array}$ \\
\hline GRO & $\begin{array}{l}2.246 * * * \\
(0.634)\end{array}$ & $\begin{array}{l}3.267 * * * \\
(0.904)\end{array}$ & $\begin{array}{l}3.827 * * * \\
(0.760)\end{array}$ \\
\hline DIS & $\begin{array}{l}3.838 * * * \\
(0.908)\end{array}$ & $\begin{array}{l}1.599 \\
(1.295)\end{array}$ & $\begin{array}{l}1.056 \\
(1.029)\end{array}$ \\
\hline HDI & $\begin{array}{l}-0.614 * * * \\
(0.243)\end{array}$ & $\begin{array}{l}-0.197 \\
(0.346)\end{array}$ & $\begin{array}{l}-0.394 \\
(0.334)\end{array}$ \\
\hline REI & $\begin{array}{l}6.354 * * * \\
(0.624)\end{array}$ & $\begin{array}{l}-6.070 * * * \\
(0.889)\end{array}$ & $\begin{array}{l}-5.571 * * * \\
(0.823)\end{array}$ \\
\hline AR & $\begin{array}{l}-1.315^{* *} \\
(0.644)\end{array}$ & $\begin{array}{l}-2.231 * * \\
(0.919)\end{array}$ & $\begin{array}{l}-1.332 \\
(0.878)\end{array}$ \\
\hline IR & $\begin{array}{l}1.187 \\
(1.774)\end{array}$ & $\begin{array}{l}8.182 * * * \\
(2.529)\end{array}$ & $\begin{array}{l}9.161 * * * \\
(2.315)\end{array}$ \\
\hline OWN & $\begin{array}{l}1.264 * * * \\
(0.262)\end{array}$ & $\begin{array}{l}-4.174 * * * \\
(0.374)\end{array}$ & $\begin{array}{l}-4.455^{* * *} \\
(0.367)\end{array}$ \\
\hline LTB & $\begin{array}{l}-0.901 * * * \\
(0.172)\end{array}$ & $\begin{array}{l}0.540 * * \\
(0.245)\end{array}$ & $\begin{array}{l}0.192 \\
(0.230)\end{array}$ \\
\hline Year FE & YES & YES & YES \\
\hline Sample size & 8757 & 8757 & 9913 \\
\hline Adj. $\mathrm{R}^{2}$ & 0.122 & 0.305 & 0.310 \\
\hline
\end{tabular}

$* * *, * *$, and $*$ represent significance at the 1,5 , and $10 \%$ levels, respectively

As the dependent variable we use the ratio of actual-to-optimal equity minus one

Standard errors in parentheses 
Table C.5 Robustness tests OLS equity utilization depending on winsorizing of regression variables

\begin{tabular}{|c|c|c|}
\hline Variable & $\begin{array}{l}\text { Original: Winsorize the premium growth } \\
\text { (GRO), the reinsurance use (REI), the ROE } \\
\text { before the calculation of the standard devia- } \\
\text { tion and the longer tailed business (LTB) to } \\
\text { the } 1 \% \text { and } 99 \% \text { percentile }\end{array}$ & $\begin{array}{l}\text { RT 6: Winsorize the premium growth } \\
\text { (GRO), the reinsurance use (REI), the ROE } \\
\text { before the calculation of the standard devia- } \\
\text { tion and the longer tailed business (LTB) to } \\
\text { the } 5 \% \text { and } 95 \% \text { percentile }\end{array}$ \\
\hline \multirow[t]{2}{*}{ Intercept } & $0.267^{*}$ & $0.318^{* *}$ \\
\hline & $(0.145)$ & $(0.147)$ \\
\hline \multirow[t]{2}{*}{ SIZ } & $-0.010^{*}$ & $-0.010^{*}$ \\
\hline & $(0.006)$ & $(0.006)$ \\
\hline \multirow[t]{2}{*}{ DIV } & $0.253 * * *$ & $0.256^{* * *} *$ \\
\hline & $(0.031)$ & $(0.031)$ \\
\hline \multirow[t]{2}{*}{ GRO } & $0.259 * * *$ & $0.205^{* *} *$ \\
\hline & $(0.046)$ & $(0.082)$ \\
\hline \multirow[t]{2}{*}{ REI } & $0.906 * * *$ & $0.897 * * *$ \\
\hline & $(0.046)$ & $(0.048)$ \\
\hline \multirow[t]{2}{*}{ AR } & $0.166^{* * *}$ & $0.174 * * *$ \\
\hline & $(0.047)$ & $(0.047)$ \\
\hline \multirow[t]{2}{*}{ IR } & $-1.226 * * *$ & $-1.927 * * *$ \\
\hline & $(0.130)$ & $(0.215)$ \\
\hline \multirow[t]{2}{*}{ OWN } & $0.047 * *$ & $0.044 * *$ \\
\hline & $(0.019)$ & $(0.019)$ \\
\hline \multirow[t]{2}{*}{ LTB } & $-0.079 * * *$ & $-0.094 * * *$ \\
\hline & $(0.013)$ & $(0.015)$ \\
\hline Year FE & YES & YES \\
\hline Sample size & 8757 & 8757 \\
\hline Adj. $\mathrm{R}^{2}$ & 0.105 & 0.098 \\
\hline
\end{tabular}

$* * *, * *$, and $*$ represent significance at the 1,5 , and $10 \%$ levels, respectively 
Table C.6 Robustness tests OLS labor utilization depending on winsorizing of regression variables

\begin{tabular}{|c|c|c|}
\hline Variable & Original & RT 6 \\
\hline Intercept & $\begin{array}{l}20.426^{* * * *} \\
(1.972)\end{array}$ & $\begin{array}{l}19.694 * * * \\
(1.990)\end{array}$ \\
\hline SIZ & $\begin{array}{l}-1.070 \text { *** } \\
(0.082)\end{array}$ & $\begin{array}{l}-1.051 * * * \\
(0.083)\end{array}$ \\
\hline DIV & $\begin{array}{l}-1.500^{* * *} \\
(0.421)\end{array}$ & $\begin{array}{l}-1.406 * * * \\
(0.422)\end{array}$ \\
\hline GRO & $\begin{array}{l}2.246 * * * \\
(0.634)\end{array}$ & $\begin{array}{l}4.770 * * * \\
(1.115)\end{array}$ \\
\hline DIS & $\begin{array}{l}3.838 * * * \\
(0.908)\end{array}$ & $\begin{array}{l}3.940 * * * \\
(0.906)\end{array}$ \\
\hline HDI & $\begin{array}{l}-0.614 * * * \\
(0.243)\end{array}$ & $\begin{array}{l}-0.538 * * \\
(0.242)\end{array}$ \\
\hline REI & $\begin{array}{l}6.354 * * * \\
(0.624)\end{array}$ & $\begin{array}{l}6.911 * * * \\
(0.645)\end{array}$ \\
\hline $\mathrm{AR}$ & $\begin{array}{l}-1.315^{* *} \\
(0.644)\end{array}$ & $\begin{array}{l}-1.239^{*} \\
(0.644)\end{array}$ \\
\hline IR & $\begin{array}{l}1.187 \\
(1.774)\end{array}$ & $\begin{array}{l}-3.126 \\
(2.923)\end{array}$ \\
\hline OWN & $\begin{array}{l}1.264 * * * \\
(0.262)\end{array}$ & $\begin{array}{l}1.278 * * * \\
(0.263)\end{array}$ \\
\hline LTB & $\begin{array}{l}-0.901 * * * \\
(0.172)\end{array}$ & $\begin{array}{l}-0.966^{* * * *} \\
(0.205)\end{array}$ \\
\hline Year FE & YES & YES \\
\hline Sample size & 8757 & 8757 \\
\hline Adj. $\mathrm{R}^{2}$ & 0.122 & 0.123 \\
\hline
\end{tabular}

$* * *, * *$, and $*$ represent significance at the 1,5 , and $10 \%$ levels, respectively

As the dependent variable we use the ratio of actual-to-optimal labor minus one

Standard errors in parentheses 
Table C.7 Regression results for labor utilization w/o and with company age

\begin{tabular}{|c|c|c|c|}
\hline Variable & Expected sign & Coefficients w/o AGE & Coefficients with AGE \\
\hline \multicolumn{4}{|l|}{ Main variables } \\
\hline Intercept & & $\begin{array}{l}20.426 * * * \\
(1.972)\end{array}$ & $\begin{array}{l}22.133^{* * * *} \\
(2.100)\end{array}$ \\
\hline Size (SIZ) & - & $\begin{array}{l}-1.070 * * * \\
(0.082)\end{array}$ & $\begin{array}{l}-1.028 * * * \\
(0.083)\end{array}$ \\
\hline Business line diversification (DIV) & - & $\begin{array}{l}-1.500 * * * \\
(0.421)\end{array}$ & $\begin{array}{l}-1.563 * * * \\
(0.422)\end{array}$ \\
\hline Premium growth (GRO) & + & $\begin{array}{l}2.246 * * * \\
(0.634)\end{array}$ & $\begin{array}{l}2.073 * * * \\
(0.638)\end{array}$ \\
\hline Distribution (DIS) & - & $\begin{array}{l}3.838 * * * \\
(0.908)\end{array}$ & $\begin{array}{l}3.728 * * * \\
(0.909)\end{array}$ \\
\hline Regional life quality (HDI) & - & $\begin{array}{l}-0.614^{* * * *} \\
(0.243)\end{array}$ & $\begin{array}{l}-0.655^{* * * *} \\
(0.243)\end{array}$ \\
\hline Age (AGE) & + & & $\begin{array}{l}-0.532^{* *} \\
(0.226)\end{array}$ \\
\hline \multicolumn{4}{|l|}{ Control variables } \\
\hline Use of reinsurance (REI) & & $\begin{array}{l}6.354 * * * \\
(0.624)\end{array}$ & $\begin{array}{l}6.477 * * * \\
(0.626)\end{array}$ \\
\hline Asset risk (AR) & & $\begin{array}{l}-1.315^{* *} \\
(0.644)\end{array}$ & $\begin{array}{l}-1.154^{*} \\
(0.648)\end{array}$ \\
\hline Income risk (IR) & & $\begin{array}{l}1.187 \\
(1.774)\end{array}$ & $\begin{array}{l}0.867 \\
(1.779)\end{array}$ \\
\hline Mutual dummy (OWN) & & $\begin{array}{l}1.264 * * * \\
(0.262)\end{array}$ & $\begin{array}{l}1.607 * * * \\
(0.300)\end{array}$ \\
\hline Longer tailed business (LTB) & & $\begin{array}{l}-0.901 * * * \\
(0.172)\end{array}$ & $\begin{array}{l}-0.950 * * * \\
(0.173)\end{array}$ \\
\hline Year fixed effects & & YES & YES \\
\hline Sample size & & 8757 & 8757 \\
\hline Adjusted $\mathrm{R}^{2}$ & & 0.122 & 0.122 \\
\hline
\end{tabular}

$* * *, * *$, and * represent significance at the 1,5 , and $10 \%$ levels, respectively

As the dependent variable we use the ratio of actual-to-optimal labor minus one

Standard errors are presented in parentheses 
Appendix D: Efficiency values from 1956 to 2019

Table D.1 Efficiency values 1956-2019

\begin{tabular}{|c|c|c|c|c|c|c|c|}
\hline Year & No. insurer & PTE & $\begin{array}{l}\text { Share of PTE } \\
\text { efficient ins } \\
(\%)\end{array}$ & $\mathrm{CE}$ & Lowest CE score & $\begin{array}{l}\text { CE rank correla- } \\
\text { tion between two } \\
\text { years }\end{array}$ & $\begin{array}{l}\text { Share of CE } \\
\text { efficient ins } \\
(\%)\end{array}$ \\
\hline 1956 & 100 & 0.76 & 31 & 0.51 & 0.08 & - & 9 \\
\hline 1957 & 100 & 0.79 & 33 & 0.54 & 0.09 & 0.98 & 9 \\
\hline 1958 & 122 & 0.79 & 30 & 0.53 & 0.09 & 0.94 & 9 \\
\hline 1959 & 128 & 0.78 & 27 & 0.52 & 0.09 & 0.95 & 8 \\
\hline 1960 & 130 & 0.79 & 31 & 0.55 & 0.11 & 0.96 & 9 \\
\hline 1961 & 131 & 0.77 & 28 & 0.52 & 0.11 & 0.97 & 8 \\
\hline 1962 & 140 & 0.78 & 31 & 0.51 & 0.10 & 0.93 & 6 \\
\hline 1963 & 140 & 0.78 & 29 & 0.5 & 0.08 & 0.97 & 7 \\
\hline 1964 & 141 & 0.76 & 24 & 0.5 & 0.09 & 0.98 & 7 \\
\hline 1965 & 146 & 0.79 & 29 & 0.52 & 0.12 & 0.97 & 6 \\
\hline 1966 & 145 & 0.73 & 22 & 0.51 & 0.11 & 0.95 & 7 \\
\hline 1967 & 149 & 0.76 & 24 & 0.51 & 0.12 & 0.97 & 5 \\
\hline 1968 & 148 & 0.78 & 26 & 0.53 & 0.13 & 0.97 & 5 \\
\hline 1969 & 151 & 0.78 & 25 & 0.53 & 0.15 & 0.94 & 7 \\
\hline 1970 & 151 & 0.76 & 19 & 0.5 & 0.07 & 0.96 & 7 \\
\hline 1971 & 151 & 0.73 & 19 & 0.5 & 0.11 & 0.94 & 7 \\
\hline 1972 & 154 & 0.72 & 17 & 0.48 & 0.11 & 0.93 & 6 \\
\hline 1973 & 159 & 0.75 & 23 & 0.49 & 0.12 & 0.98 & 6 \\
\hline 1974 & 154 & 0.77 & 19 & 0.52 & 0.08 & 0.83 & 8 \\
\hline 1975 & 161 & 0.73 & 18 & 0.47 & 0.08 & 0.88 & 6 \\
\hline 1976 & 159 & 0.78 & 20 & 0.5 & 0.10 & 0.95 & 6 \\
\hline 1977 & 161 & 0.8 & 23 & 0.52 & 0.11 & 0.97 & 6 \\
\hline 1978 & 160 & 0.8 & 18 & 0.53 & 0.10 & 0.94 & 6 \\
\hline 1979 & 163 & 0.81 & 21 & 0.54 & 0.12 & 0.98 & 6 \\
\hline 1980 & 164 & 0.8 & 21 & 0.57 & 0.14 & 0.98 & 7 \\
\hline 1981 & 168 & 0.81 & 22 & 0.56 & 0.04 & 0.95 & 7 \\
\hline 1982 & 170 & 0.82 & 23 & 0.56 & 0.04 & 0.94 & 8 \\
\hline 1983 & 173 & 0.82 & 23 & 0.55 & 0.07 & 0.95 & 7 \\
\hline 1984 & 175 & 0.82 & 24 & 0.57 & 0.07 & 0.98 & 7 \\
\hline 1985 & 177 & 0.81 & 20 & 0.57 & 0.07 & 0.97 & 8 \\
\hline 1986 & 178 & 0.83 & 20 & 0.59 & 0.10 & 0.96 & 7 \\
\hline 1987 & 180 & 0.84 & 26 & 0.59 & 0.10 & 0.94 & 10 \\
\hline 1988 & 179 & 0.84 & 27 & 0.6 & 0.10 & 0.96 & 9 \\
\hline 1989 & 175 & 0.83 & 26 & 0.56 & 0.09 & 0.97 & 6 \\
\hline 1990 & 180 & 0.83 & 27 & 0.54 & 0.08 & 0.98 & 6 \\
\hline 1991 & 184 & 0.81 & 20 & 0.52 & 0.10 & 0.96 & 5 \\
\hline 1992 & 190 & 0.83 & 22 & 0.54 & 0.04 & 0.96 & 6 \\
\hline 1993 & 185 & 0.85 & 27 & 0.54 & 0.05 & 0.97 & 6 \\
\hline
\end{tabular}


Table D.1 (continued)

\begin{tabular}{|c|c|c|c|c|c|c|c|}
\hline Year & No. insurer & PTE & $\begin{array}{l}\text { Share of PTE } \\
\text { efficient ins } \\
(\%)\end{array}$ & $\mathrm{CE}$ & Lowest CE score & $\begin{array}{l}\text { CE rank correla- } \\
\text { tion between two } \\
\text { years }\end{array}$ & $\begin{array}{l}\text { Share of CE } \\
\text { efficient ins } \\
(\%)\end{array}$ \\
\hline 1994 & 185 & 0.86 & 28 & 0.56 & 0.05 & 0.97 & 5 \\
\hline 1995 & 183 & 0.85 & 26 & 0.56 & 0.06 & 0.96 & 5 \\
\hline 1996 & 186 & 0.87 & 30 & 0.56 & 0.05 & 0.94 & 5 \\
\hline 1997 & 179 & 0.85 & 27 & 0.55 & 0.08 & 0.95 & 4 \\
\hline 1998 & 178 & 0.86 & 28 & 0.56 & 0.06 & 0.96 & 5 \\
\hline 1999 & 171 & 0.86 & 27 & 0.55 & 0.05 & 0.95 & 6 \\
\hline 2000 & 171 & 0.83 & 27 & 0.57 & 0.05 & 0.95 & 8 \\
\hline 2001 & 165 & 0.86 & 29 & 0.57 & 0.05 & 0.95 & 7 \\
\hline 2002 & 164 & 0.86 & 26 & 0.57 & 0.07 & 0.97 & 8 \\
\hline 2003 & 159 & 0.88 & 30 & 0.59 & 0.08 & 0.96 & 8 \\
\hline 2004 & 159 & 0.87 & 25 & 0.55 & 0.10 & 0.90 & 4 \\
\hline 2005 & 148 & 0.85 & 28 & 0.60 & 0.11 & 0.96 & 8 \\
\hline 2006 & 146 & 0.87 & 26 & 0.63 & 0.13 & 0.92 & 8 \\
\hline 2007 & 140 & 0.85 & 24 & 0.57 & 0.13 & 0.95 & 7 \\
\hline 2008 & 149 & 0.86 & 28 & 0.61 & 0.11 & 0.96 & 9 \\
\hline 2009 & 149 & 0.84 & 28 & 0.57 & 0.09 & 0.96 & 8 \\
\hline 2010 & 147 & 0.83 & 29 & 0.57 & 0.10 & 0.97 & 9 \\
\hline 2011 & 143 & 0.85 & 31 & 0.57 & 0.08 & 0.98 & 8 \\
\hline 2012 & 140 & 0.84 & 27 & 0.56 & 0.10 & 0.99 & 11 \\
\hline 2013 & 140 & 0.85 & 25 & 0.56 & 0.09 & 0.98 & 10 \\
\hline 2014 & 137 & 0.85 & 27 & 0.55 & 0.11 & 0.98 & 10 \\
\hline 2015 & 133 & 0.85 & 29 & 0.57 & 0.11 & 0.97 & 9 \\
\hline 2016 & 131 & 0.86 & 27 & 0.58 & 0.11 & 0.95 & 9 \\
\hline 2017 & 129 & 0.87 & 28 & 0.58 & 0.11 & 0.97 & 11 \\
\hline 2018 & 125 & 0.87 & 29 & 0.57 & 0.10 & 0.97 & 10 \\
\hline 2019 & 120 & 0.87 & 33 & 0.59 & 0.10 & 0.99 & 8 \\
\hline
\end{tabular}




\section{Appendix E: Efficiency comparison direct vs. non-direct insurers}

Table E.1 Efficiency comparison between direct and non-direct insurers

\begin{tabular}{|c|c|c|c|c|c|}
\hline Year & $\begin{array}{l}\text { No. direct } \\
\text { insurer }\end{array}$ & $\begin{array}{l}\text { No. non-direct } \\
\text { insurer }\end{array}$ & $\mathrm{CE}$ direct insurer & $\begin{array}{l}\text { CE non-direct } \\
\text { insurer }\end{array}$ & $\begin{array}{l}p \text { value } \\
\text { Wilcoxon test }\end{array}$ \\
\hline 1989 & 1 & 174 & 0.35 & 0.56 & 0.40 \\
\hline 1990 & 1 & 179 & 0.25 & 0.54 & 0.21 \\
\hline 1991 & 1 & 183 & 0.23 & 0.53 & 0.17 \\
\hline 1992 & 2 & 188 & 0.15 & 0.54 & $0.03 * * *$ \\
\hline 1993 & 5 & 180 & 0.21 & 0.56 & $0.00 * * *$ \\
\hline 1994 & 4 & 181 & 0.14 & 0.57 & $0.00 * * *$ \\
\hline 1995 & 5 & 178 & 0.25 & 0.58 & $0.01 * * *$ \\
\hline 1996 & 6 & 180 & 0.20 & 0.57 & $0.00^{* * *}$ \\
\hline 1997 & 8 & 171 & 0.37 & 0.56 & $0.05 * *$ \\
\hline 1998 & 7 & 171 & 0.39 & 0.57 & $0.08 *$ \\
\hline 1999 & 6 & 165 & 0.40 & 0.55 & 0.16 \\
\hline 2000 & 6 & 165 & 0.47 & 0.58 & 0.39 \\
\hline 2001 & 6 & 159 & 0.52 & 0.57 & 0.68 \\
\hline 2002 & 6 & 158 & 0.52 & 0.57 & 0.74 \\
\hline 2003 & 6 & 153 & 0.54 & 0.59 & 0.63 \\
\hline 2004 & 6 & 153 & 0.49 & 0.56 & 0.44 \\
\hline 2005 & 7 & 141 & 0.58 & 0.60 & 0.90 \\
\hline 2006 & 7 & 139 & 0.60 & 0.64 & 0.60 \\
\hline 2007 & 7 & 133 & 0.49 & 0.58 & 0.33 \\
\hline 2008 & 7 & 142 & 0.56 & 0.62 & 0.49 \\
\hline 2009 & 8 & 141 & 0.48 & 0.59 & 0.27 \\
\hline 2010 & 8 & 139 & 0.49 & 0.58 & 0.33 \\
\hline 2011 & 8 & 135 & 0.49 & 0.58 & 0.36 \\
\hline 2012 & 7 & 133 & 0.47 & 0.57 & 0.30 \\
\hline 2013 & 7 & 133 & 0.46 & 0.57 & 0.28 \\
\hline 2014 & 6 & 131 & 0.49 & 0.57 & 0.45 \\
\hline 2015 & 5 & 128 & 0.50 & 0.58 & 0.49 \\
\hline 2016 & 5 & 126 & 0.50 & 0.58 & 0.52 \\
\hline 2017 & 5 & 124 & 0.47 & 0.58 & 0.33 \\
\hline 2018 & 5 & 120 & 0.44 & 0.57 & 0.29 \\
\hline 2019 & 5 & 115 & 0.45 & 0.59 & 0.23 \\
\hline All & 173 & 4718 & 0.44 & 0.57 & $0.00^{* * *}$ \\
\hline
\end{tabular}

$* * *, * *$, and $*$ represent significance at the 1,5 , and $10 \%$ levels, respectively

For this analysis we used the estimated equity and debt prices as well as the labor book values 
Table E.2 Efficiency comparison between direct and non-direct insurers

\begin{tabular}{|c|c|c|c|c|c|}
\hline Year & $\begin{array}{l}\text { No. direct } \\
\text { insurer }\end{array}$ & $\begin{array}{l}\text { No. non-direct } \\
\text { insurer }\end{array}$ & $\mathrm{CE}$ direct insurer & $\begin{array}{l}\text { CE non-direct } \\
\text { insurer }\end{array}$ & $\begin{array}{l}p \text { value } \\
\text { Wilcoxon test }\end{array}$ \\
\hline 1983 & 1 & 189 & 0.11 & 0.46 & $0.09 *$ \\
\hline 1984 & 1 & 190 & 0.13 & 0.44 & $0.09 *$ \\
\hline 1985 & 2 & 196 & 0.56 & 0.45 & 0.96 \\
\hline 1986 & 2 & 198 & 0.29 & 0.44 & 0.46 \\
\hline 1987 & 2 & 202 & 0.45 & 0.46 & 0.81 \\
\hline 1988 & 1 & 204 & 0.24 & 0.47 & 0.17 \\
\hline 1989 & 3 & 199 & 0.31 & 0.47 & 0.30 \\
\hline 1990 & 3 & 205 & 0.15 & 0.44 & $0.01 * *$ \\
\hline 1991 & 3 & 212 & 0.29 & 0.51 & 0.13 \\
\hline 1992 & 4 & 218 & 0.19 & 0.44 & $0.01 * * *$ \\
\hline 1993 & 7 & 212 & 0.39 & 0.42 & 0.81 \\
\hline 1994 & 6 & 214 & 0.39 & 0.44 & 0.26 \\
\hline 1995 & 8 & 208 & 0.30 & 0.48 & $0.03 * *$ \\
\hline 1996 & 9 & 210 & 0.24 & 0.47 & $0.00 * * *$ \\
\hline 1997 & 11 & 202 & 0.44 & 0.57 & $0.04 * *$ \\
\hline 1998 & 11 & 201 & 0.51 & 0.56 & 0.33 \\
\hline 1999 & 10 & 193 & 0.34 & 0.50 & $0.02 * *$ \\
\hline 2000 & 10 & 196 & 0.41 & 0.53 & 0.12 \\
\hline 2001 & 11 & 189 & 0.46 & 0.57 & 0.12 \\
\hline 2002 & 11 & 188 & 0.50 & 0.48 & 0.60 \\
\hline 2003 & 11 & 181 & 0.61 & 0.55 & 0.48 \\
\hline 2004 & 10 & 181 & 0.64 & 0.57 & 0.47 \\
\hline 2005 & 11 & 169 & 0.61 & 0.54 & 0.46 \\
\hline 2006 & 11 & 167 & 0.59 & 0.57 & 0.74 \\
\hline 2007 & 10 & 160 & 0.55 & 0.55 & 0.89 \\
\hline 2008 & 11 & 170 & 0.53 & 0.55 & 0.98 \\
\hline 2009 & 14 & 169 & 0.51 & 0.54 & 0.84 \\
\hline 2010 & 14 & 168 & 0.47 & 0.50 & 0.81 \\
\hline 2011 & 13 & 163 & 0.46 & 0.50 & 0.54 \\
\hline 2012 & 13 & 159 & 0.53 & 0.54 & 0.92 \\
\hline 2013 & 13 & 158 & 0.59 & 0.55 & 0.41 \\
\hline 2014 & 11 & 157 & 0.58 & 0.54 & 0.48 \\
\hline 2015 & 10 & 153 & 0.55 & 0.55 & 0.83 \\
\hline 2016 & 10 & 150 & 0.56 & 0.53 & 0.61 \\
\hline 2017 & 8 & 148 & 0.56 & 0.53 & 0.64 \\
\hline 2018 & 8 & 144 & 0.50 & 0.48 & 0.89 \\
\hline 2019 & 8 & 140 & 0.54 & 0.53 & 0.84 \\
\hline All & 302 & 6763 & 0.48 & 0.50 & 0.23 \\
\hline
\end{tabular}

$* * *, * *$, and $*$ represent significance at the 1,5 , and $10 \%$ levels, respectively

For this analysis we used the estimated equity and debt prices as well as the estimated labor number (ratio of operating and labor expenses). Therefore, more direct insurers exist 


\section{Appendix F: Stochastic Frontier analysis}

For the analysis of the technical efficiency, we use a translog stochastic input distance function, because of its broad usage in insurance literature (e.g., Bikker and van Leuvensteijn 2008; Eling and Luhnen 2010a). Following Bogetoft and Otto (2011) we use the translog function for our SFA model:

Table F.1 SFA efficiency values 1956-2019

\begin{tabular}{|c|c|c|c|c|c|}
\hline Year & No. insurer & SFA efficiency & Year & No. insurer & SFA efficiency \\
\hline 1956 & 100 & 0.89 & 1988 & 179 & 0.94 \\
\hline 1957 & 100 & 0.90 & 1989 & 175 & 0.94 \\
\hline 1958 & 122 & 0.90 & 1990 & 180 & 0.94 \\
\hline 1959 & 128 & 0.90 & 1991 & 184 & 0.93 \\
\hline 1960 & 130 & 0.90 & 1992 & 190 & 0.91 \\
\hline 1961 & 131 & 0.90 & 1993 & 185 & 0.92 \\
\hline 1962 & 140 & 0.89 & 1994 & 185 & 0.92 \\
\hline 1963 & 140 & 0.88 & 1995 & 183 & 0.93 \\
\hline 1964 & 141 & 0.88 & 1996 & 186 & 0.93 \\
\hline 1965 & 146 & 0.89 & 1997 & 179 & 0.93 \\
\hline 1966 & 145 & 0.90 & 1998 & 178 & 0.92 \\
\hline 1967 & 149 & 0.90 & 1999 & 171 & 0.93 \\
\hline 1968 & 148 & 0.91 & 2000 & 171 & 0.93 \\
\hline 1969 & 151 & 0.91 & 2001 & 165 & 0.92 \\
\hline 1970 & 151 & 0.91 & 2002 & 164 & 0.92 \\
\hline 1971 & 151 & 0.91 & 2003 & 159 & 0.93 \\
\hline 1972 & 154 & 0.91 & 2004 & 159 & 0.93 \\
\hline 1973 & 159 & 0.91 & 2005 & 148 & 0.93 \\
\hline 1974 & 154 & 0.92 & 2006 & 146 & 0.93 \\
\hline 1975 & 161 & 0.91 & 2007 & 140 & 0.93 \\
\hline 1976 & 159 & 0.93 & 2008 & 149 & 0.93 \\
\hline 1977 & 161 & 0.93 & 2009 & 149 & 0.91 \\
\hline 1978 & 160 & 0.92 & 2010 & 147 & 0.92 \\
\hline 1979 & 163 & 0.93 & 2011 & 143 & 0.93 \\
\hline 1980 & 164 & 0.92 & 2012 & 140 & 0.92 \\
\hline 1981 & 168 & 0.92 & 2013 & 140 & 0.92 \\
\hline 1982 & 170 & 0.93 & 2014 & 137 & 0.93 \\
\hline 1983 & 173 & 0.93 & 2015 & 133 & 0.93 \\
\hline 1984 & 175 & 0.93 & 2016 & 131 & 0.93 \\
\hline 1985 & 177 & 0.93 & 2017 & 129 & 0.93 \\
\hline 1986 & 178 & 0.94 & 2018 & 125 & 0.93 \\
\hline 1987 & 180 & 0.93 & 2019 & 120 & 0.93 \\
\hline
\end{tabular}


Table G.1 Efficiency values 1956-2019

\begin{tabular}{|c|c|c|c|c|c|}
\hline Year & No. insurer & Efficiency & Year & No. insurer & Efficiency \\
\hline 1956 & 100 & 0.55 & 1988 & 179 & 0.62 \\
\hline 1957 & 100 & 0.56 & 1989 & 175 & 0.57 \\
\hline 1958 & 122 & 0.56 & 1990 & 180 & 0.56 \\
\hline 1959 & 128 & 0.56 & 1991 & 184 & 0.54 \\
\hline 1960 & 130 & 0.59 & 1992 & 190 & 0.56 \\
\hline 1961 & 131 & 0.55 & 1993 & 185 & 0.57 \\
\hline 1962 & 140 & 0.55 & 1994 & 185 & 0.58 \\
\hline 1963 & 140 & 0.53 & 1995 & 183 & 0.58 \\
\hline 1964 & 141 & 0.53 & 1996 & 186 & 0.57 \\
\hline 1965 & 146 & 0.55 & 1997 & 179 & 0.57 \\
\hline 1966 & 145 & 0.54 & 1998 & 178 & 0.58 \\
\hline 1967 & 149 & 0.55 & 1999 & 171 & 0.56 \\
\hline 1968 & 148 & 0.57 & 2000 & 171 & 0.58 \\
\hline 1969 & 151 & 0.57 & 2001 & 165 & 0.58 \\
\hline 1970 & 151 & 0.54 & 2002 & 164 & 0.58 \\
\hline 1971 & 151 & 0.56 & 2003 & 159 & 0.60 \\
\hline 1972 & 154 & 0.52 & 2004 & 159 & 0.57 \\
\hline 1973 & 159 & 0.53 & 2005 & 148 & 0.61 \\
\hline 1974 & 154 & 0.54 & 2006 & 146 & 0.65 \\
\hline 1975 & 161 & 0.50 & 2007 & 140 & 0.57 \\
\hline 1976 & 159 & 0.52 & 2008 & 149 & 0.62 \\
\hline 1977 & 161 & 0.53 & 2009 & 149 & 0.58 \\
\hline 1978 & 160 & 0.54 & 2010 & 147 & 0.58 \\
\hline 1979 & 163 & 0.56 & 2011 & 143 & 0.59 \\
\hline 1980 & 164 & 0.57 & 2012 & 140 & 0.56 \\
\hline 1981 & 168 & 0.57 & 2013 & 140 & 0.58 \\
\hline 1982 & 170 & 0.58 & 2014 & 137 & 0.58 \\
\hline 1983 & 173 & 0.58 & 2015 & 133 & 0.59 \\
\hline 1984 & 175 & 0.58 & 2016 & 131 & 0.60 \\
\hline 1985 & 177 & 0.59 & 2017 & 129 & 0.60 \\
\hline 1986 & 178 & 0.60 & 2018 & 125 & 0.60 \\
\hline 1987 & 180 & 0.61 & 2019 & 120 & 0.62 \\
\hline
\end{tabular}

$$
\begin{aligned}
\log \left(\frac{1}{I_{m}}\right)= & a_{0}+\sum_{i=1}^{m-1} a_{i} \log \left(\frac{I_{i}}{I_{m}}\right)+\sum_{j=1}^{n} b_{j} \log O_{j} \frac{1}{2} \sum_{i=1}^{m-1} \sum_{j=1}^{m-1} A_{i j} \log \left(\frac{I_{i}}{I_{m}}\right) \log \left(\frac{I_{j}}{I_{m}}\right) \\
& +\frac{1}{2} \sum_{i=1}^{n} \sum_{j=1}^{n} B_{i j} \log O_{i} \log O_{j}+\frac{1}{2} \sum_{i=1}^{m-1} \sum_{j=1}^{n} C_{i j} \log \left(\frac{I_{i}}{I_{m}}\right) \log O_{j}+v-u
\end{aligned}
$$

where $I$ is an $M \times S$ input matrix, $O$ is an $N \times S$ matrix of all outputs produced by all insurer. $I_{m}$ and $O_{n}$ are the $S \times 1$ input $m$ / output $n$ vectors for all insurers. We assume that $v$ and $u$ are independent, $v$ is normally distributed $v \sim N\left(0, \sigma_{v}^{2}\right)$ and $u$ is half-normally 
distributed $u \sim N_{+}\left(0, \sigma_{u}^{2}\right)$. The translog function is calculated for each year from 1956 through 2019 and we obtain the SFA efficiency values presented in Table F.1.

\section{Appendix G: Efficiency values with additional quality indicator}

It is common procedure in the insurance domain to use the value-added approach, which considers the risk-pooling and financial services functions of insurance companies via net losses (i.e., paid losses plus additions to reserves) and the financial intermediation function via the value of total investments (see, e.g., Cummins and Weiss 2013). This approach neglects potential additional output dimensions such as differences in product quality. There is no generally accepted quality indicator for insurance companies widely used in efficiency analyses. However, academic research agrees that the most important quality dimension of an insurance product is insurer's financial strength that is the ability to meet obligations (Zanjani 2002).

We consider the financial strength measured by the Solvency I ratio, which in our sample period has been the predominant regulatory measures to assess whether insurers are able to meet their obligations. The Solvency I ratio relates the existing equity capital to premium and claims indices (Eling et al. 2007). Table G.1 presents the efficiency values when we add the Solvency I ratio to the existing set of output variables. Overall, the efficiency values remain on a very comparable level, with a correlation of 0.98 between the results presented in Table G.1. and those presented in the main body of the text.

Funding Open access funding provided by University of St.Gallen.

Open Access This article is licensed under a Creative Commons Attribution 4.0 International License, which permits use, sharing, adaptation, distribution and reproduction in any medium or format, as long as you give appropriate credit to the original author(s) and the source, provide a link to the Creative Commons licence, and indicate if changes were made. The images or other third party material in this article are included in the article's Creative Commons licence, unless indicated otherwise in a credit line to the material. If material is not included in the article's Creative Commons licence and your intended use is not permitted by statutory regulation or exceeds the permitted use, you will need to obtain permission directly from the copyright holder. To view a copy of this licence, visit http://creativecommons.org/licen ses/by/4.0/.

\section{References}

Ahn H, Le MH (2015) DEA efficiency of German savings banks: evidence from a goal-oriented perspective. J Bus Econ 85:953-975

Autor D, Dorn D (2013) The growth of low skill service jobs and the polarization of the US labor market. Am Econ Rev 103(5):1553-1597

Autor D, Levy F, Murnane RJ (2003) The skill content of recent technological change: an empirical exploration. Quart J Econ 118(4):1279-1333

Berger AN, Cummins JD, Weiss MA (1997) The coexistence of multiple distribution systems for financial services: the case of property-liability insurance. J Bus 70(4):515-546

Biener C, Eling M, Wirfs JH (2016) The determinants of efficiency and productivity in the Swiss insurance industry. Eur J Oper Res 248(2):703-714

Bikker JA, van Leuvensteijn M (2008) Competition and efficiency in the Dutch life insurance industry. Appl Econ 40(16):2063-2084 
Bogetoft P, Otto L (2011) Benchmarking with DEA, SFA, and R. Springer, New York

Bohnert A, Fritzsche A, Gregor S (2019) Digital agendas in the insurance industry: the importance of comprehensive approaches. Geneva Paper Risk Insur Issues Pract 44(1):1-19

Braun A, Schmeiser H, Rymaszewski P (2015) Stock vs. mutual insurers: who should and who does charge more? Eur J Operational Res 242(3):875-889

Bonin H, Gregory T, Zierahn U (2015) Übertragung der Studie von Frey/Osborne (2013) auf Deutschland. ZEW Kurzexpertise No. 57, Zentrum für Europäische Wirtschaftsforschung (ZEW), Mannheim

Brynjolfsson E, McAfee A (2011) Race against the machine: how the digital revolution is accelerating innovation, driving productivity, and irreversibly transforming employment and the economy. Digital Frontier Press, Lexington, MA

Charnes A, Cooper WW, Rhodes E (1978) Measuring the efficiency of decision making units. Eur J Oper Res 2(6):429-444

Choudhry MT (2009) Determinants of labor productivity: an empirical investigation of productivity divergence. Working Paper

Craig BJ, Pardey PG, Roseboom J (1997) International productivity patterns: accounting for input quality, infrastructure, and research. Am J Agr Econ 79(4):1064-1076

Cummins JD, Nini GP (2002) Optimal capital utilization by financial firms: evidence from the propertyliability insurance industry. J Financial Serv Res 21(1-2):15-53

Cummins JD, Rubio-Misas M (2006) Deregulation, consolidation, and efficiency: evidence from the Spanish insurance industry. J Money, Credit, Bank 38(2):323-355

Cummins JD, Weiss MA (2013) Analyzing firm performance in the insurance industry using frontier efficiency and productivity methods. Handbook of insurance. Springer, New York, pp 795-861

Cummins JD, Xie X (2008) Mergers and acquisitions in the US property-liability insurance industry: productivity and efficiency effects. J Bank Finance 32(1):30-55

Cummins JD, Xie X (2013) Efficiency, productivity, and scale economies in the US property-liability insurance industry. J Prod Anal 39(2):141-164

Cummins JD, Zi H (1998) Comparison of frontier efficiency methods: an application to the US life insurance industry. J Prod Anal 10(2):131-152

Cummins JD, Rubio-Misas M, Zi H (2004) The effect of organizational structure on efficiency: evidence from the Spanish insurance industry. J Bank Finance 28(12):3113-3150

Cummins JD, Weiss MA, Zi H (1999) Organizational form and efficiency: the coexistence of stock and mutual property-liability insurers. Manage Sci 45(9):1254-1269

Cummins JD, Weiss MA, Xie X, Zi H (2010) Economies of scope in financial services: a DEA efficiency analysis of the US insurance industry. J Bank Finance 34(7):1525-1539

Dellnitz A, Kleine A, Rödder W (2018) CCR or BCC: what if we are in the wrong model? J Bus Econ $88: 831-850$

Deloitte (2018) The future of talent in insurance. Retrieved from https://www2.deloitte.com/content/dam/ Deloitte/ie/Documents/FinancialServices/IE_FS_talentinInsurance_0918_FINAL3.pdf, Accessed 31 Mar 2020

Duetsch M, Struck O (2014) Atypical employment and the risks for preservation of occupational skills. German J Ind Relat 21(1):58-77

Dyckhoff H, Ahn H (2010) Verallgemeinerte DEA-Modelle zur Performanceanalyse. Z Betriebswirt 80:1249-1276

Eling M, Hoyt RE, Schaper P (2020) The impact of capacity on price and productivity change in insurance markets. J Insur Issues 43(1):22-58

Eling M, Lehmann M (2018) The impact of digitalization on the insurance value chain and the insurability of risks. Geneva Paper Risk Insur Issues Pract 43(3):359-396

Eling M, Luhnen M (2010a) Efficiency in the international insurance industry: a cross-country comparison. J Bank Finance 34(7):1497-1509

Eling M, Luhnen M (2010b) Frontier efficiency methodologies to measure performance in the insurance industry: overview, systematization, and recent developments. Geneva Paper Risk Insur Issues Pract 35(2):217-265

Eling M, Schaper P (2017) Under pressure: how the business environment affects productivity and efficiency of European life insurance companies. Eur J Oper Res 258(3):1082-1094

Eling M, Schmeiser H, Schmit JT (2007) The Solvency II process: overview and critical analysis. Risk Manag Insur Rev 10(1):69-85 
Fandel G, Lorth M (2010) Technische Ineffizienz als Ergebnis rationalen Entscheidungsverhaltens. Z Betriebswirt 80:477-494

Farrell MJ (1957) The measurement of productive efficiency. J Roy Stat Soc 120(3):253-281

Frey CB, Osborne MA (2017) The future of employment: how susceptible are jobs to computerization? Technol Forecast Soc Chang 114:254-280

Goldin C, Katz LF (1998) The origins of technology-skill complementarity. Quart J Econ 113(3):693-732

Gomber P, Koch JA, Siering M (2017) Digital Finance and FinTech: current research and future research directions. J Bus Econ 87:537-580

Goos M, Manning A (2007) Lousy and lovely jobs: the rising polarization of work in Britain. Rev Econ Stat 89(1):118-133

Goos M, Manning A, Salomons A (2014) Explaining job polarization: routine-biased technological change and offshoring. Am Econ Rev 104(8):2509-2526

Harris SE, Katz JL (1991) Organizational performance and information technology investment intensity in the insurance industry. Organ Sci 2(3):263-295

Hussels S, Ward DR (2007) The impact of deregulation on the German and UK life insurance markets: an analysis of efficiency and productivity between 1991 and 2002. Working Paper, SOM Research Paper Series 4/07, Cranfield University

Johansson S, Vogelgesang U (2015) Insurance on the threshold of digitization: implications for the life and p\&c workforce. McKinsey \& Company. Retrieved from http://www.mckinsey.com/industries/ financial-services/our-insights/insurance-on-the-threshold-of-digitization, Accessed 31 Mar 2020

Kaffash S, Azizi R, Huang Y, Zhu J (2020) A survey of data envelopment analysis applications in the insurance industry 1993-2018. Eur J Oper Res 284(3):801-813

Katz LF, Murphy KM (1992) Changes in relative wages, 1963-1987: supply and demand factors. Quart J Econ 107(1):35-78

Leibenstein H (1966) Allocative efficiency vs. "X-efficiency.” Am Econ Rev 56(3):392-415

Leung D, Meh C, Terajima Y (2008) Firm size and productivity. Staff Working Papers 08-45, Bank of Canada

Luhnen M (2009) Determinants of efficiency and productivity in German property-liability insurance: evidence for 1995-2006. Geneva Paper Risk Insur Issues Pract 34(3):483-505

Mahlberg B, Url T (2003) Effects of the single market on the Austrian insurance industry. Empirical Econ 28:813-838

Mahlberg B, Url T (2010) Single market effects on productivity in the German insurance industry. J Bank Finance 34(7):1540-1548

Malhotra R (2015) The insurance workforce of the future: why will so many insurers fail to achieve their digital potential? Accenture strategy. Retrieved from https:/www.accenture.com/t00010101t00000 0_w__it-it/_acnmedia/accenture/ conversion-assets/dotcom/documents/global/pdf/dualpub_25/ accenture-the-insurance-workforce-of-the-future.pdf, Accessed 31 Mar 2020

Sandner K, Sieber S, Tellermann M, Walthes F (2020) A Lean Six Sigma framework for the insurance industry: insights and lessons learned from a case study. J Bus Econ 90:845-878

Schwab K (2016) The fourth industrial revolution. Penguin Random House, UK

Spitz-Oener A (2006) Technical change, job tasks, and rising educational demands: looking outside the wage structure. J Law Econ 24(2):235-270

Stuebs M, Sun L (2010) Business reputation and labor efficiency, productivity, and cost. J Bus Ethics 96:265-283

Swiss Re Institute (2019). World insurance: the great pivot east continues. Swiss Re sigma No. 3/2019. Retrieved from https://www.swissre.com/institute/research/sigma-research/sigma-2019-03.html. Accessed 31 Mar 2020

Trigo-Gamarra L, Growitsch C (2010) Comparing single- and multichannel distribution strategies in the German life insurance market: an analysis of cost and profit efficiency. Schmalenbach Bus Rev 62(4):401-417

Van Ark B, Monnikhof E (1996) Size distribution of output and employment: a data set for manufacturing industries in five OECD countries, 1960s-1990. OECD Economics Department Working Papers No. 166

Zanjani G (2002) Pricing and capital allocation in catastrophe insurance. J Financ Econ 65(2):283-305

Publisher's Note Springer Nature remains neutral with regard to jurisdictional claims in published maps and institutional affiliations. 